I NTER NATIONAL MONETARY FUND
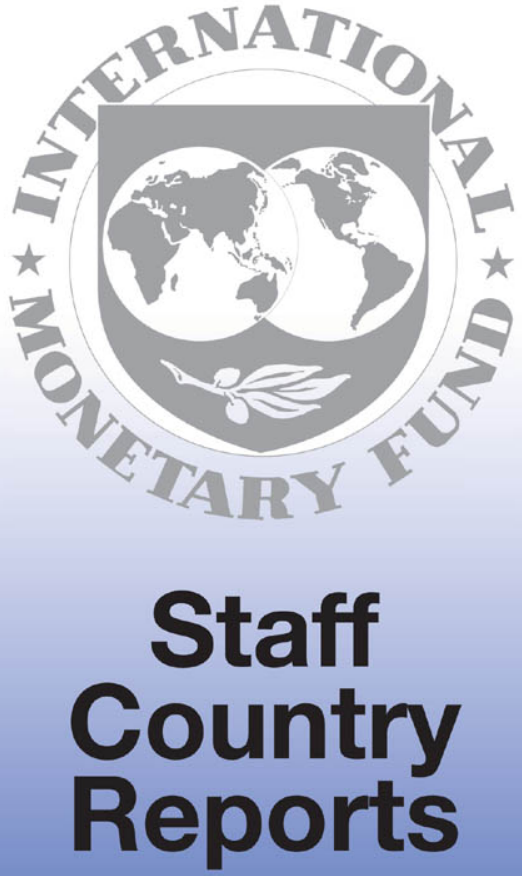
The report of the International Monetary Fund (IMF) — Stand-By Arrangement—Review Under the Emergency Financing Mechanism - presents the findings of an IMF staff visit to Athens during June 14-18, 2010. The visit was conducted in cooperation with the European Commission and the ECB. The purpose of the visit was to conduct an interim review of economic developments and policy implementation, as called for under the Fund's Emergency Financing Mechanism (EFM). The report confirms the preliminary conclusions of the interim mission, (see Press Release No. 10/246). In particular, the program appears to be broadly on track as authorities are making considerable progress in putting public finances on a sustainable path and are implementing major reforms, including of the pension system, ahead of schedule. A more comprehensive review of the program is scheduled for July 26August 6, 2010. Completion of this comprehensive review by the Fund's Executive Boardexpected in early September-will make the next tranche under the stand-by arrangement of SDR 2.1627 billion (about US\$3.27 billion) available to the Greek authorities. 


\section{Greece: Stand-By Arrangement- Review Under the Emergency Financing Mechanism}

This paper was prepared based on the information available at the time it was completed on Wednesday, June 30, 2010. The views expressed in this document are those of the staff team and do not necessarily reflect the views of the government of Greece or the Executive Board of the IMF.

The policy of publication of staff reports and other documents by the IMF allows for the deletion of market-sensitive information.

Copies of this report are available to the public from

International Monetary Fund • Publication Services

700 19th Street, N.W. • Washington, D.C. 20431

Telephone: (202) 623-7430 • Telefax: (202) 623-7201

E-mail: publications@imf.org • Internet: http://www.imf.org

\section{International Monetary Fund \\ Washington, D.C.}


INTERNATIONAL MONETARY FUND

\title{
GREECE
}

\section{Stand-By Arrangement—Review Under the Emergency Financing Mechanism}

\author{
Prepared by the European Department in Consultation with Other Departments
}

Approved by Poul Thomsen and Martin Mühleisen

June 30,2010

\section{Executive Summary}

- Overarching strategy of the program. The authorities are making progress to put the public finances on a sustainable path, complemented with structural reforms to boost competitiveness and growth, while seeking an equitable distribution of the adjustment burden across all levels of society and protecting the most vulnerable.

- Economic activity is declining as expected with the downturn projected to become more acute as the year goes on. The decline is led by cuts in government spending, with some latent buoyancy in private consumption. Inflation is running higher than expected as indirect tax increases are not (even partially) absorbed in margins. Unit labor costs are, however, moderating considerably, and unemployment is rising.

- State budget implementation is on track with good expenditure control. However, hospitals and social security funds present clear risks, as do financial pressures in public enterprises. These three areas are not directly controlled by the state budget and require more attention. The pension reform contains significant reductions in future pension costs, even though it is not clear that the authorities can bring them down from 12.5 ppts of GDP before the reform to 2.5 ppts in one step, as aimed in the program. A full actuarial assessment of the reform will take more time than foreseen in the program.

- Banks face continued liquidity pressures and some solvency erosion but plans are in place to deal with this. Sharp downgrades of the sovereign led to margin calls on collateralized borrowing. Deposits also are quite soft. That said, the European Central Bank (ECB) is assisting Greek banks to tide them over the liquidity crunch. NPLs are rising but banks' capital remains well above the regulatory minimum and the Financial Stability Fund is nearly in place.

- Structural reforms are progressing. The authorities announced a privatization program, labor reforms, a local government reform, and initiatives to liberalize closed professions. They are ahead of schedule in setting up a public sector employment and wage census.

- Discussions took place on June 14-18 with the Minister of Finance, Governor of the Bank of Greece (BoG), Minister of Labor and Social Security, Minister of Interior, and staff in these and other ministries and agencies, and private banks.

- Staff comprised P. Thomsen (head), B. Traa, G. Everaert, M. Moreno Badia (all EUR); S. Eble and M. Soto (FAD); and Y. Sun (SPR). O. Frecaut and L. Zanforlin (MCM) and B. Jansen and A. Gullo (LEG) conducted a parallel TA mission on the Financial Stability Fund, and assisted the interim review mission, as did two parallel FAD TA teams in Public Financial Management and Expenditure Policy. 


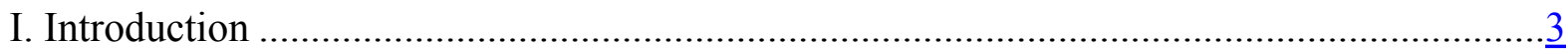

II. Recent Developments and Outlook ...............................................................................

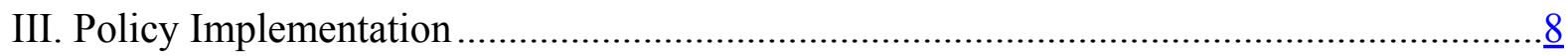

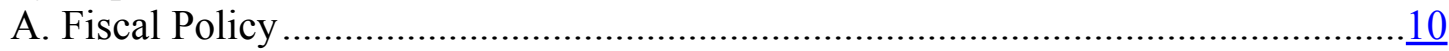

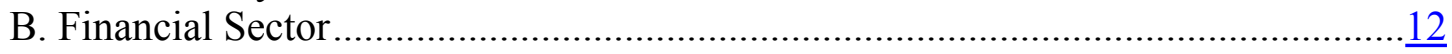

C. Structural Policy and Data Reporting...............................................................

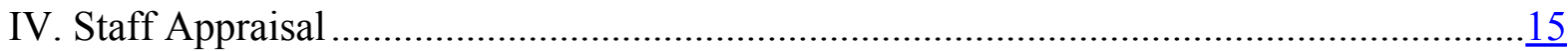

Boxes

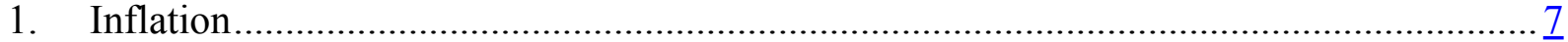

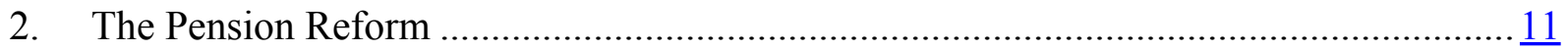

3. Update on the Financial Stability Fund ………........................................................

4. Public Sector Employment and Wages Census ............................................................ 15

Figures

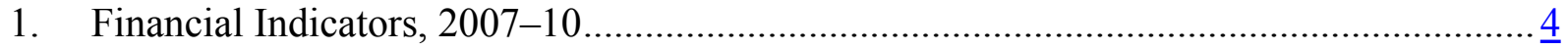

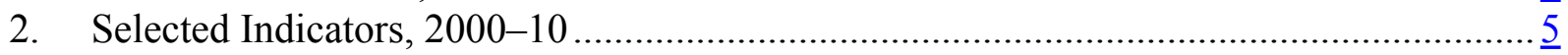

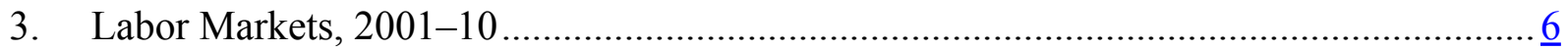

4. Money and Banking Indicators, 2005-10 …….........................................................

Tables

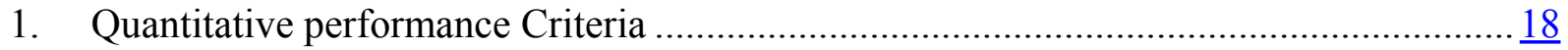

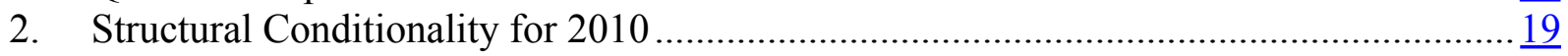

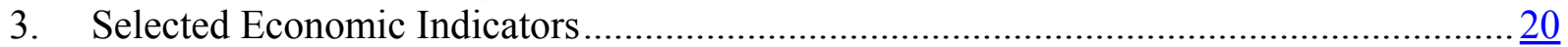

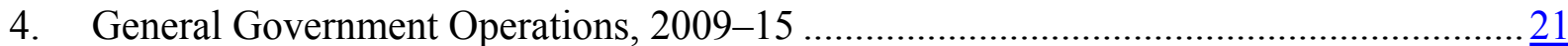

5. Public Sector Financing Requirements and Sources .................................................

6. Summary of Balance Payments, 2009-15 ………....................................................

7. External Financing Requirements and Sources, 2008-15 …...................................24

8. Core Set of Financial Soundness Indicators for Deposit Taking Institutions, 2000-10 .. $\underline{25}$

9. Access and Phasing under the Proposed Stand-By Arrangement, 2010-13 ..................... 26

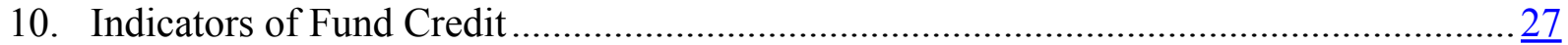

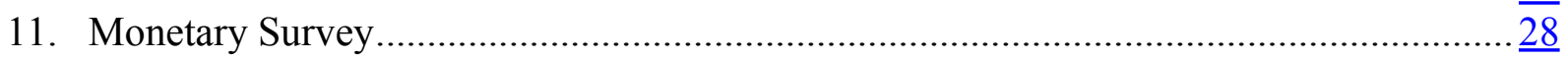

12 Modified General Government Cash Balance for Program Monitoring. .......................... 29 


\section{INTRODUCTION}

1. The mission took place in the context of the Emergency Financing Mechanism (EFM). On May 9, 2010 the Executive Board approved a three-year Stand-By Arrangement (SBA) for Greece under the EFM in the amount of SDR 26.4 billion (3,212 percent of quota). The first purchase was $€ 5.5$ billion (SDR4.8 billion) upon SBA approval. The euro-zone partner countries committed $€ 80$ billion, and made a first disbursement of $€ 14.5$ billion. The EFM procedures call for a full review of the initial policy response and the reaction of markets to these policies within one to two months of the approval of the arrangement.

\section{RECENT DEVELOPMENTS AND OUTLOOK}

2. Markets are still skeptical and spreads are too high. Sovereign spreads dropped sharply after the stand-by arrangement was approved, also supported by the ECB purchases of Greek bonds - which are estimated at some $€ 25$ billion to date. ${ }^{1}$ Nevertheless, after Moody's 4-notch downgrade of the Greek sovereign on June 14 to below investment grade, the benchmark 10-year bond spread over equivalent German issues rose again and reached close to 800 bps subsequently, amid thin market trading (Figure 1). ${ }^{2}$ In the wake of this downgrade, some continued pressure is evident as many index funds now have to divest their holdings of Greek bonds. Speculation that Greek debt restructuring may have only been postponed, rather than decisively put to rest, clearly weighs on sentiment. Evidence needs to build that the program is being fully implemented, supported by social consensus and with prospects for a growth recovery.

\section{Economic activity is contracting in line with expectations, but inflation is higher} than anticipated. The drop in Q1 real GDP by 2.5 percent (year-on-year) was in line with program projections and driven by a sharp cut in public consumption and investment (Figure 2). Private consumption was surprisingly resilient reflecting possibly some capture of previously informal activity following a tax-administration campaign that obliges vendors to issue VAT receipts to clients. Further, preliminary data up to March show that the external trade deficit remained high reflecting higher oil prices and increased payments for ship orders, reflecting a recovery in the shipping industry. ${ }^{3}$ Imports excluding oil and ships declined (by 6.5 percent year-on-year), while exports and tourism still were soft. Unemployment edged up to 10.8 percent (SA) by end-March 2010 (Figure 3). Year-on-year inflation reached 5.3 percent at end-May, with an apparent large pass-through to prices of the excise and VAT measures (Box 1).

\footnotetext{
${ }^{1}$ The policy agreement on the large package of measures for the program was announced in early May, but the spreads continued to rise until the day of approval in the Board and the announcement, on the same day, of the new European Support Mechanism.

${ }^{2}$ Moody's had been an outlier, rating Greece much higher than S\&P and Fitch, so a catch up downgrade was not unexpected. Nevertheless, the large jump down unsettled the markets.

${ }^{3}$ Some delayed EU transfers widened the CA deficit in Q1, but are expected to help in Q2.
} 
Figure 1. Greece: Financial Indicators, 2007-10

The stock market is down $\mathrm{y} / \mathrm{y} \ldots$

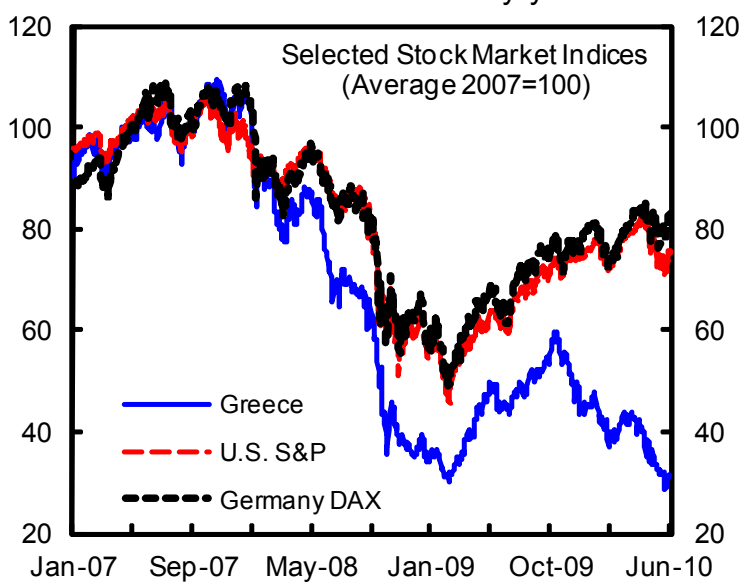

Banks' spreads are increasing.

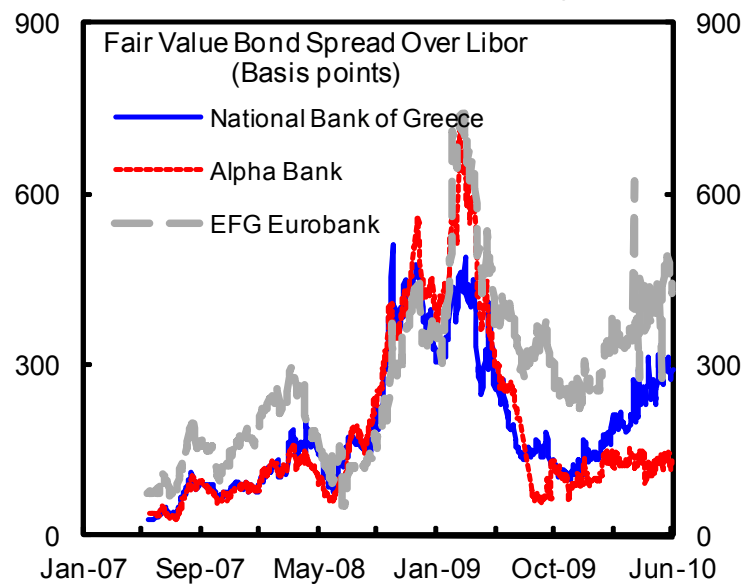

...and long-maturity end...

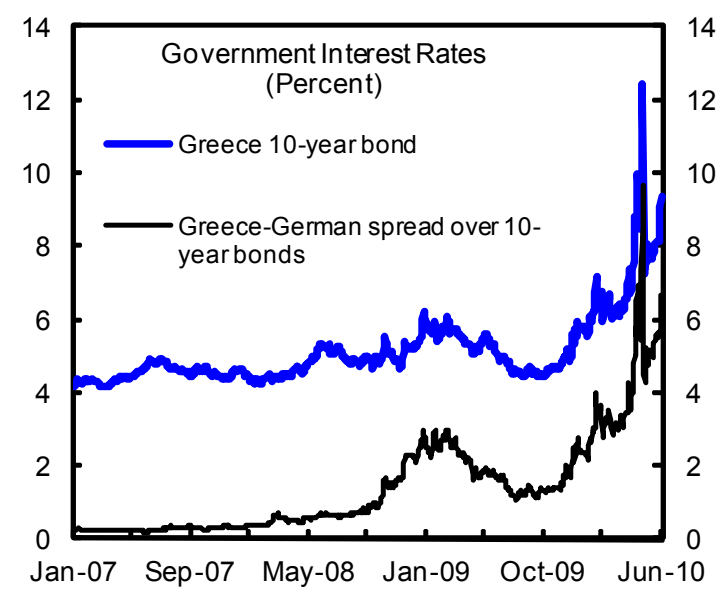

...led by bank equities.

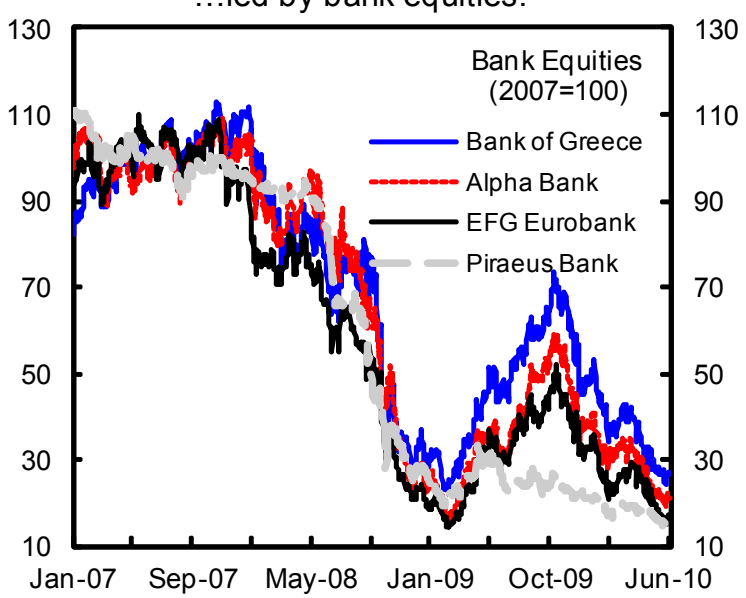

Sovereign spreads are up in the short-...

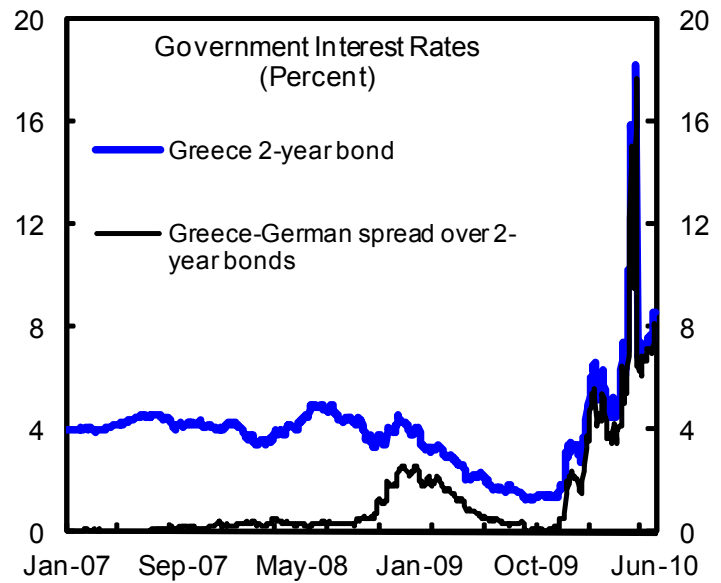

....as are credit default swaps spreads.

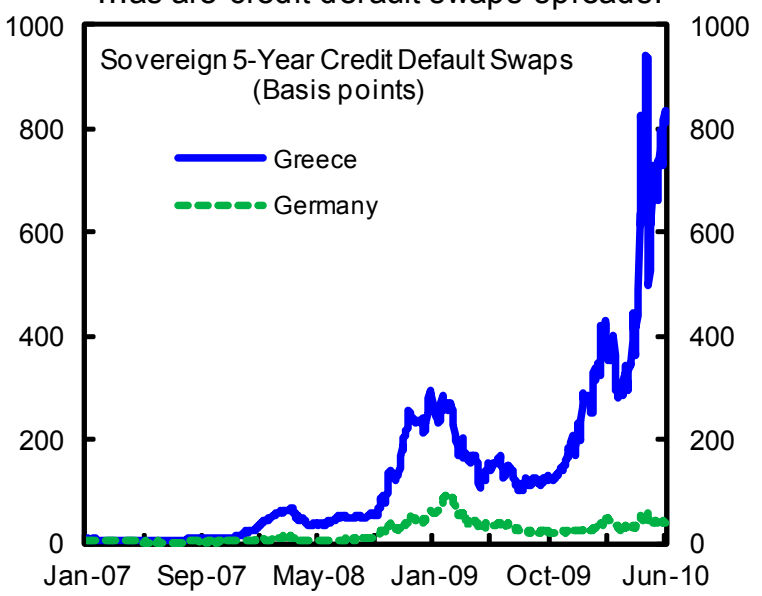

Sources: Bloomberg; and Moody's Creditedge. 
Figure 2. Greece: Selected Indicators, 2000-10

(Year-on-year percent change, unless otherwise indicated)
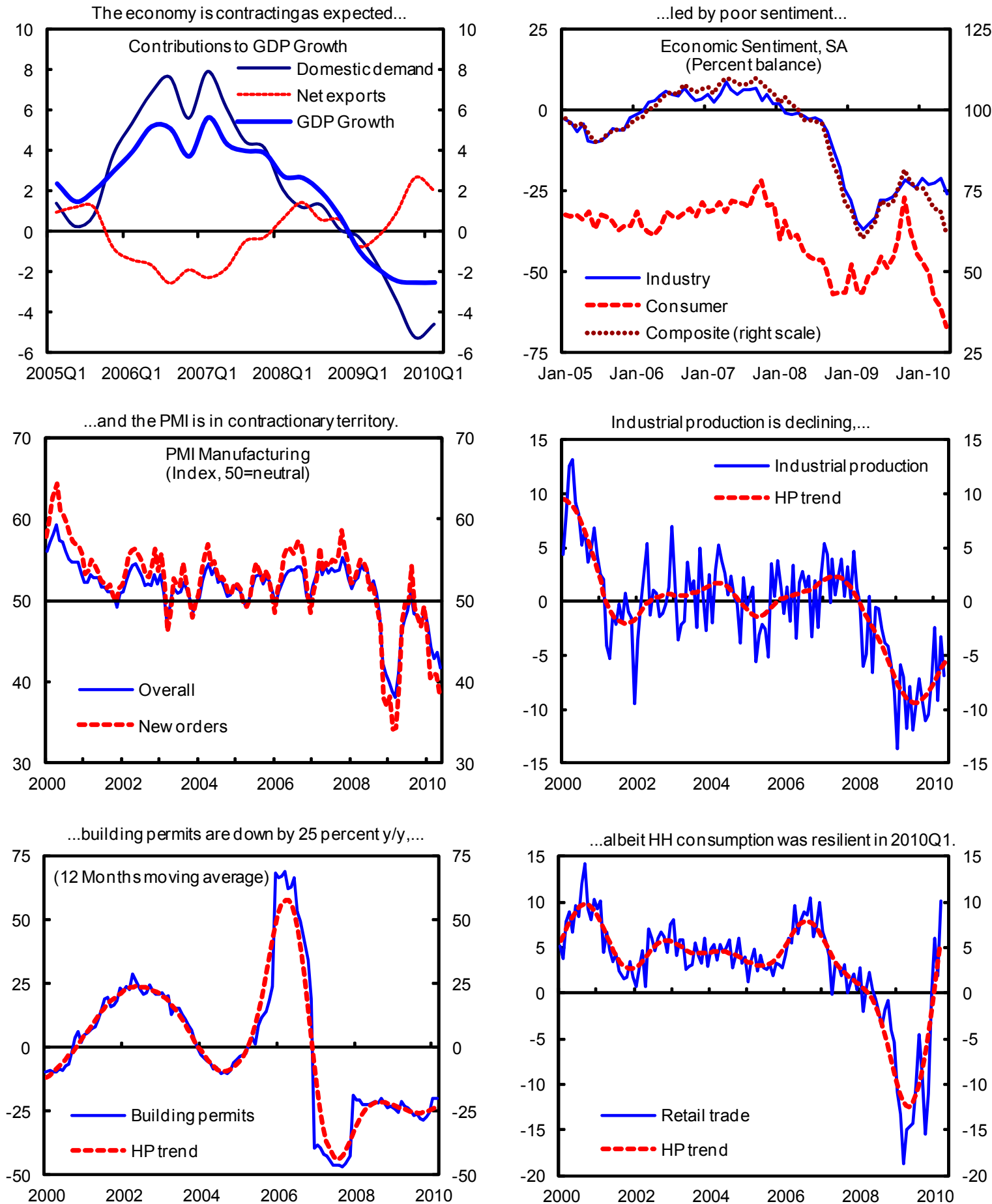

So urces: National Statistical Service; Eurostat; and IMF staff calculations an d estimates. 
Figure 3. Greece: Labor Markets, 2001-10

(Year-on-year percent change, unless otherwise indicated)
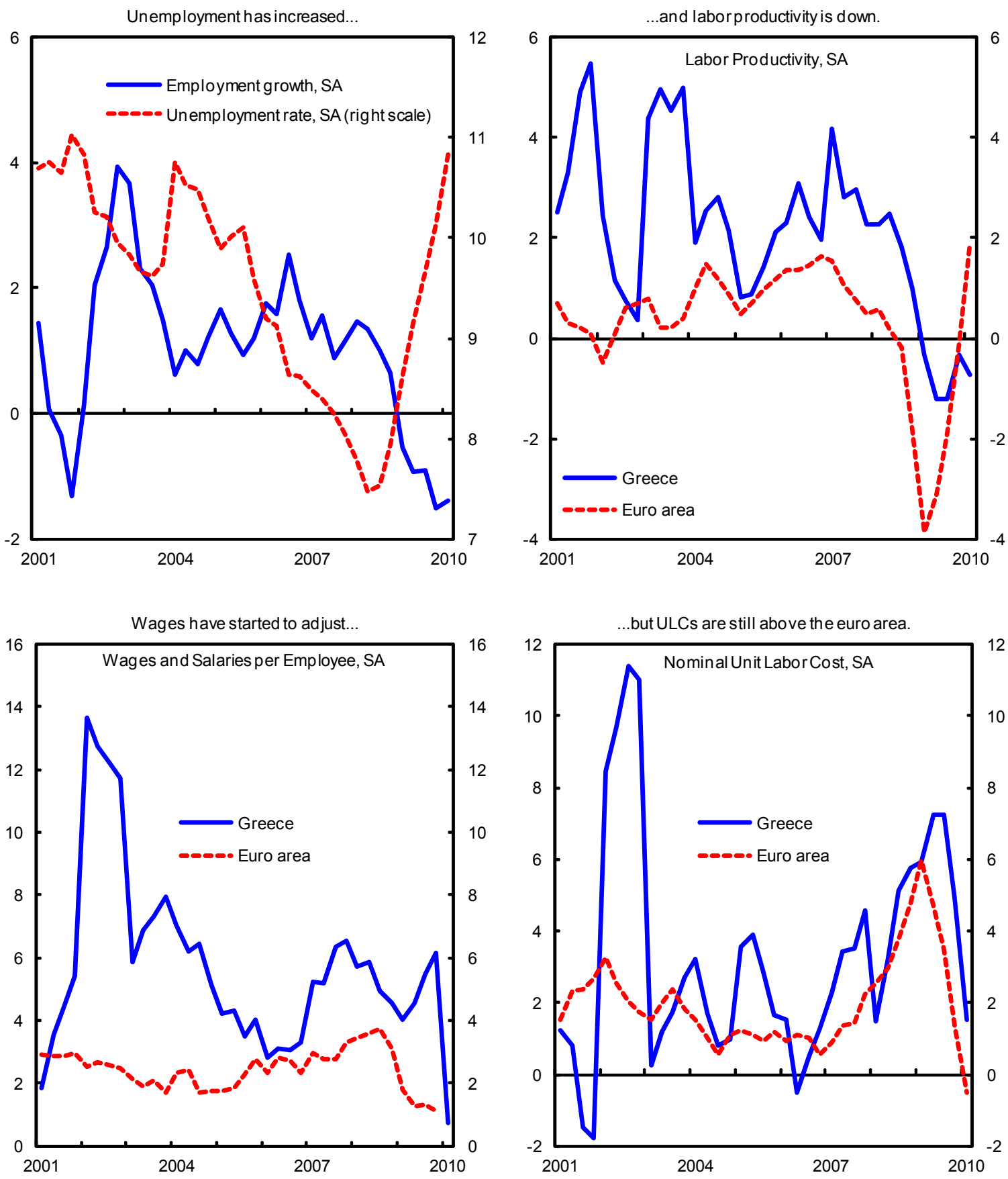

Sources: Eurostat; and IMF staff cal culations. 


\section{Box 1. Inflation}

Inflation developments up to May reflect indirect tax increases. May inflation can be decomposed into the effect of tax increases (4 ppts) and non-tax price developments (1.3 ppts). The tax contribution to inflation has increased from 16 percent in January to 74 percent in May, while non-tax related price inflation has been falling only gradually.

Nontax downward price rigidities are a clear concern. The very high pass-through of indirect taxes to final prices is indicative of poorly contested domestic markets - an area where structural reforms are crucial. Inflation at constant taxes, while falling, remains relatively high despite sharply falling activity. The impression is that unit labor costs are at last moderating, but margins are rigid, and suppliers' competition insufficient.
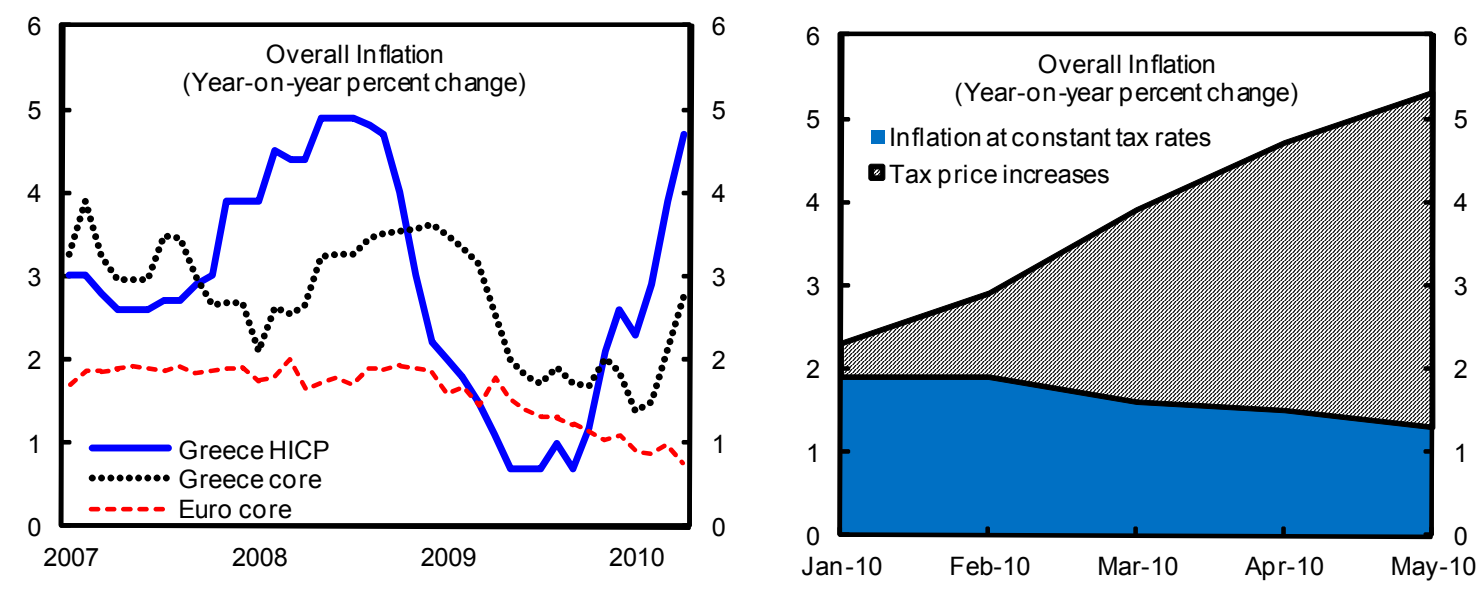

Sources: Eurostat; ELSTAT; and IMF staff estimates and calculations.

\section{The state budget deficit reduction is broadly on track even though there are}

risks. The January-May cash balance of the state budget (including military spending) was much better than programmed (by $€ 3.5$ billion, or 1.5 percent of GDP), reflecting overall revenues largely on track, and strong spending control. Available data through April however suggest that health care costs are running high and that social security and local government accounts are underperforming (by $€ 1.5$ billion, or 0.6 percent of GDP), which partially offsets the strong state budget performance. Meanwhile, financing conditions for state-owned enterprises have been affected by the sovereign crisis and an estimated $€ 1.5$ billion in guarantees could be called during 2010, which would increase the debt, as has occurred in the past. 


\section{The banking sector remains under strain.}

Liquidity conditions are tight. Banks face difficulties in renewing liabilities as market confidence has not yet been restored and spreads have not yet resumed their downward trend. The Moody's 4-notch downgrade on June 14 triggered further margin calls, leading to additional collateral needs, including with the ECB. While Greek sovereign paper remains eligible with the ECB, it is subject to a 5 percent higher haircut, because the recent downgrade means that two rating agencies now rate Greece as non-investment grade. This put renewed pressure on banks' liquidity positions, which had gotten some respite after the program approval and ECB bond market assistance. Nevertheless, the approval of a banking support package for $€ 15$ billion in additional guarantees in May and continued ECB liquidity assistance have bolstered the resistance of the banking system (Figure 4).

- Banks' solvency buffers remain adequate, with some erosion. As expected, the quality of banks' loan portfolios declined slowly with the economic downturn. NPLs increased from 7.7 percent of total loans in December 2009 to 8.2 percent as of end-March 2010 and the NPL coverage ratio with provisions has dropped. The system-wide capital adequacy ratio declined from 13.2 percent in December 2009 to 12.9 percent as of end-March 2010, as foreseen, but remains well above the 8 percent regulatory minimum. Partial data available for April and May 2010 indicate further slippage, with some differentiation among banks. Although banks' pre-provisioning operating income has remained stable at elevated levels, the need for larger provisions against NPLs has driven the banking system as a whole into a loss after including provisioning and taxes.

\section{Policy Implementation}

\section{Key commitments are being implemented and there is progress toward} medium-term reforms, yet challenges remain. Implementation of agreed fiscal policies is delivering results as the authorities appear broadly on track to comply with end-June quantitative PCs. There is also progress on structural reforms, not least what is set to be a substantial overhaul of the pension system, with significant TA involvement. Banking sector stability is challenging but is being maintained - with the ECB crucially helping banks meet their funding needs - and with progress to establish the FSF. The authorities are working hard to address challenges in the face of stretched capacity to implement multiple program points. 
Figure 4. Greece: Money and Banking Indicators, 2005-10
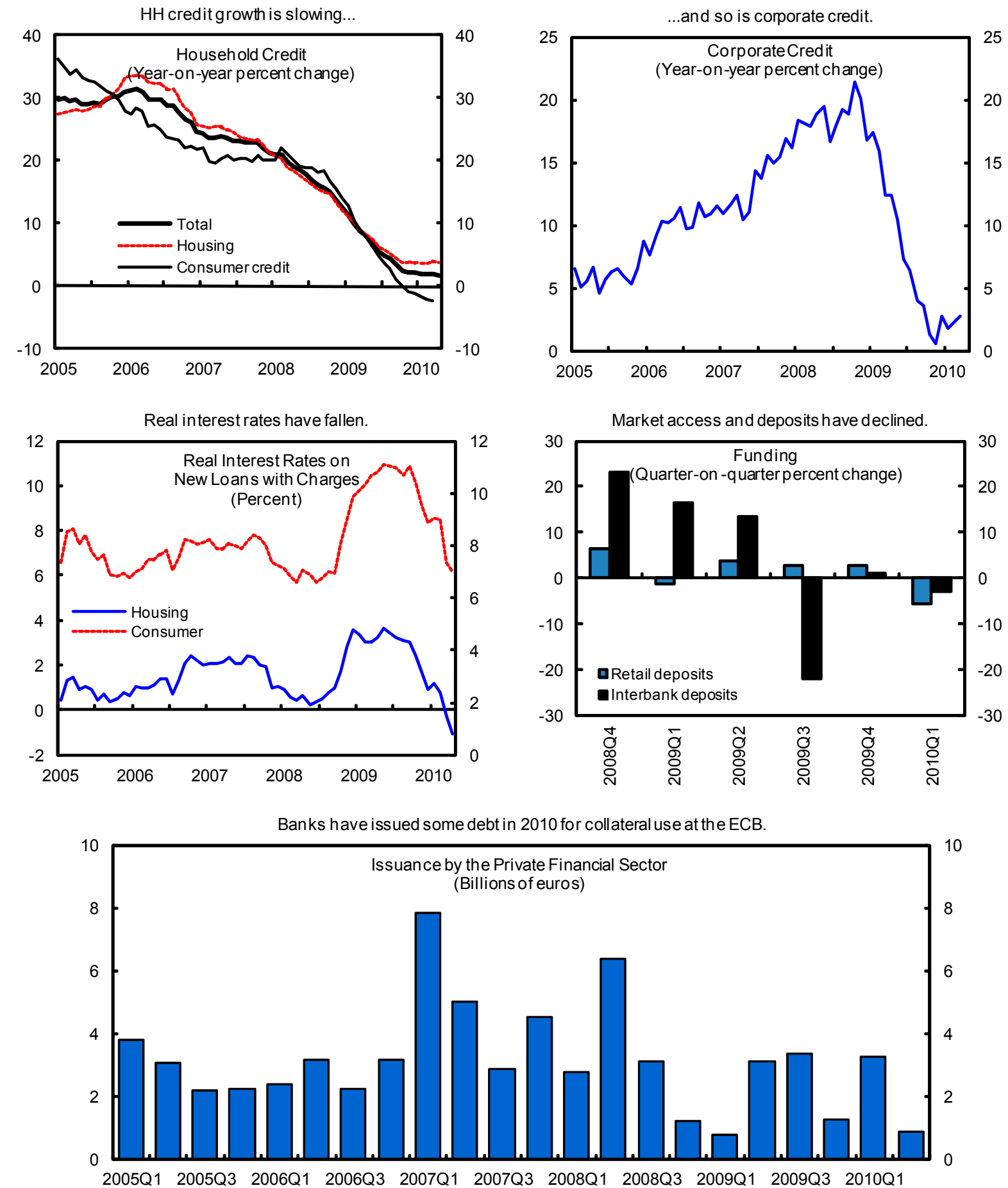

Sources: National Statistical Service; Bank of Greece; Bloomberg; ECB; and IMF staff calculations. 


\section{A. Fiscal Policy}

\section{Implementation is progressing and risks need to be managed to ensure the} program remains on track. Nearly all fiscal measures for 2010 have been implemented ${ }^{4}$, and are expected to yield a boost to revenue and another round of savings in the second half of the year. However, performance in the health sector, social security, local governments, and in public enterprises could deteriorate, posing risks. ${ }^{5}$ In health, accounts payable have increased to an estimated $€ 840$ million, and are planned to be reduced over the next 4-6 months. This is crucial so that these do not spill over into becoming arrears - a problem that has occurred in the past. A monitoring mechanism for arrears is being developed but is still not fully in place. Also, owing to project implementation delays and administrative lags, delays in structural EU fund disbursements may not be fully overcome during this year, despite good faith efforts, and revenue from EU funds' disbursements could thus still come in weaker. ${ }^{6}$ The authorities have been taking actions to deal with those risks through tight execution of discretionary state budget spending, reductions in the costs of pharmaceuticals (20 percent price cut in an approved "drugs list" and tight monitoring of prescriptions), closer monitoring of hospital budgets, and advancing with the privatization program. Also, TA is helping to establish commitment registers, identify contingency measures, and firm up medium-term expenditure savings. Program monitoring has improved as the authorities strengthened internal budget forecasting, monitoring, and reporting in line with program requirements with assistance from $\mathrm{EC} / \mathrm{ECB} / \mathrm{Fund}$ staff.

8. Progress on improving fiscal management is underway. To strengthen overall fiscal strategy and implementation, the fiscal management bill (end-June structural benchmark) will introduce an annual rolling three-year fiscal and budget strategy for the consolidated general government; establish top-down budgeting with medium-term expenditure ceilings for the state budget; strengthen commitment controls; require supplementary budgets for overspending; modernize fiscal audits; and strengthen accountability and transparency including by creating a parliamentary budget office. Preparation of the draft law is supported by IMF technical assistance and it is expected to be in parliament by end-June.

9. The draft pension bill is making progress... The draft bill introduces a flat pension and a proportional component and includes changes to key parameters that will reduce future pension costs significantly such as through lower average replacement rates and higher effective retirement ages (Box 2).

\footnotetext{
${ }^{4}$ The reduction in the higher pensions (savings of $€ 350$ million) and in pensions of the power and telecoms company employees (savings of $€ 150$ million) await final steps to become effective.

${ }^{5}$ Also, the growing guarantee program for the financial sector implies a buildup of contingent risks; even though this does not have a fiscal cash flow implication in the very short run other than fees for the government.

${ }^{6} \mathrm{EU}$ structural funds are earmarked for investment spending, thus their delay has little effect on the deficit, but it could affect growth in the economy.
} 


\section{Box 2. The Pension Reform}

The reform seeks to improve long-run sustainability of the retirement system, simplify the system, and increase labor force participation. The staff estimates that the proposed changes will substantially slow down the increase in pension spending through 2060, which could come down from 12.5 ppts of GDP to around 4-6 ppts of GDP (the main source of uncertainty relates to costs of supplementary pensions, which require further analysis). Key reform elements are:

- Accrual rates/generosity: The old system has different accrual rates across pension plans. The new law proposes one profile of accrual rates for all workers, bringing these down from 2-3 percent a year to a much lower range of $0.80-1.50$ percent a year, depending on the years of service. This measure simplifies the pension system and reduces costs. It creates incentives to participate longer as the accrual rate is progressive with working life.

- $\quad$ Retirement age/years of contributions: The old system often allowed workers to claim full benefits before age 60 . The proposed system sets the minimum age of retirement at 60 for all workers (men and women); requires 40 years of contributions to receive full benefits; and reduces benefits by 6 percent a year for those who claim before age 65 without 40 years of contributions. In addition, the two anchors ( 60 and 65 years of age) will be indexed to life expectancy going forward.

- Arduous professions: The reform requires a revision of the list of arduous occupations to reduce claims in these categories.

- Calculation of pensionable earnings: The current system uses the top 5 years of the last 10 years of earnings as the pensionable base. The new law will use the full earnings history to calculate pensionable earnings.

- Indexation of pensions: The current system tends to adjust pensions with wage growth. The proposed system caps indexation at inflation.

- $\quad$ Simplification: the new law merges some 13 funds into three, roughly corresponding to those for private sector workers, the self-employed, and other remaining categories of workers.

- Safeguard clause: if actuarial analysis suggests that the reform falls somewhat short of the final objective to reduce increases in future pension costs to 2.5 ppts of GDP, then a Ministerial Decision can lower costs further by a combination of adjusting parameters of the system, the basic pension, and supplementary pensions to achieve the final objective.

10. ...even though an actuarial evaluation may take more time to be completed. The National Actuarial Authority (NAA) has engaged in the time-consuming task of integrating the main components of the reform into its models. A full actuarial assessment of the reform will not be ready for the end-June structural benchmark. Nonetheless, the NAA is likely to provide a basic evaluation of the impact of the proposed reform on the largest pension plans by the first review mission scheduled for end-July. Preliminary results suggest that the reform will reduce incremental pension spending substantially (perhaps by $6 \frac{1}{2}-81 / 2$ ppts of GDP), which is short of the goal of bringing down the incremental pension costs over the 
period 2010-2060 by 10 ppts of GDP (from 12.5 ppts of GDP) as aimed for in the program. The authorities are committed to engage in subsequent further cost-reductions to deliver the intended goal if the more complete actuarial results indicate that this were necessary. However, because the political window of opportunity is narrow, the authorities want to bring the bill on this ambitious reform to parliament before its summer recess, even before the actuarial studies are finished.

\section{The authorities are confident that they can place T-bills in July and October,} despite difficult market conditions. The demand for T-bills by Greek banks remains strong, buoyed also by the liquidity support from the ECB, although non-resident demand may be muted. The authorities plan to continue accessing the T-bill market during the program period on a regular basis to facilitate short-term cash management for the budget and gradually to prepare the way for opening up access to longer-dated maturities.

\section{B. Financial Sector}

\section{The authorities are taking further measures to support bank liquidity. The} measures taken so far have proved crucial and preserved the stability of the system. Nevertheless, the margins of safety they provide have been compressed by the effects of the latest downgrade and the authorities aim to restore comfort through an additional installment, currently under study, of new government guarantees (which could provide increased collateral at the ECB).

13. The Financial Stability Fund (FSF) is nearly in place. Substantial progress - with detailed inputs from the EC, ECB, and IMF - has been made in the finalization of the legislation on the FSF (Box 3 ) to ensure that this capital backstopping facility becomes available soon. The legal establishment of the FSF is an end-June structural benchmark and the authorities are expected to provide the financing for the fund in September and December. In the unlikely case that earlier financing were needed, this could be bridged with T-bill placements or by drawing down cash balances. An update of stress test is planned for September to incorporate the latest developments on potential capital injection needs.

\section{Private-sector exposure to Greece is difficult to gauge because of confidentiality} provisions, which is complicating engagement of PSI. Foreign regulators are prevented from sharing available data on bank exposures to Greece with the ECB and the Fund because of confidentiality restrictions. Preliminary statistics (from the BIS and other sources) indicate that Greek banks' liability to non-resident financial institutions have remained broadly stable, but no precise data are available. Announcements by German, French, and Dutch banks to maintain exposures to Greek debt coincided with their home countries' parliamentary votes on the Greece support package. German banks have committed to uphold credit lines and report exposures to the German regulator. Thin trading volume in Greek paper suggests little change in investor composition, although precise information on this is sketchy. The authorities are considering a road show following completion of the first review, when the first critical set of achievements under the program is available, to bolster further support for Greece and improve investor sentiment. 


\section{Box 3. Update on the Financial Stability Fund}

- $\quad$ Establishment. The legislation for the FSF is expected to be approved by Parliament in July. The FSF will be endowed with $€ 10$ billion to be disbursed in equal installments in September and December.

- Governance. The Board will be composed of seven members, five of which will be nominated by the Governor of the Bank of Greece and then appointed by the latter and the Minister of Finance. The remaining two members wil be the Deputy Governor of the Bank of Greece and the Secretary General of the Ministry of Finance, acting on an ex officio basis. The entity will be independent and autonomous. Internal auditing functions will be established to ensure good governance. The FSF will provide monthly balance sheets and annual audited financial statements to the Greek Parliament, Minister of Finance, Governor of BoG, and the Greece staff teams of the EC, ECB, and the Fund.

- Capital support for banks: Modalities of capital injection will vary depending on the initial capital of banks:

(1) Capital above regulatory limits but declining. In this case, banks can request access to the FSF or the BoG could recommend the institution to apply if it fails to raise additional capital in the market. The FSF will decide to provide resources following presentation of a restructuring plan and a recommendation of the BoG. Capital is injected through preference shares which would be converted into common shares if targets identified under the restructuring plan are breached or if the capital ratios are not complied with.

(2) Capital below pillar 2. The BoG will have the power to impose sanctions as provided for in the banking law if the credit institution fails to follow the BoG recommendations. The BoG may recommend that the FSF invest in the credit institution. The terms of the support provided by the FSF will be the same as above.

(3) Capital below pillar 1. Subject to a recommendation of the BoG, the FSF will provide support to the credit institution upon presentation of a strong restructuring plan and only after a formal audit of the accounts to ensure all existing losses are recognized and absorbed by existing shareholders. In this case the FSF will only provide common shares.

Alternatively, instead of taking the measures described under (2) and (3) above, the BoG may also appoint a commissioner or revoke the license of the problem banks. 


\section{Structural Policy and Data Reporting}

\section{The authorities are making progress with the large structural reform agenda:}

- $\quad$ The sub-central government reform (Kallikratis) was approved in Parliament (end-June structural benchmark), and a reorganization of local governments and their multiple entities has started. This will reduce the number of local administrations, entities, and elected and appointed officials, with important fiscal savings although final estimates are lacking. At the same time, the law envisages some devolution of powers to the local authorities. Assurances should be put in place that spending control and borrowing at the sub-national level remains tight, and fiscal policy remains well-coordinated across the general government.

- $\quad$ Progress is being made with establishing the Single Payment Authority, which will improve transparency and control over the wage bill (Box 4).

- The government is launching much-needed reforms in the important public enterprise sector. In railways, legislation is being prepared to restructure the train operator. In addition, the government has announced a privatization agenda, which will be further discussed at the time of the first review.

- Other areas where legislation is currently in the drafting stage include a significant labor market reform and liberalization of road transportation (trucking). Preparatory work on structural reforms in the product markets is ongoing with heavy involvement of the EC (particularly on the Services Directive and the liberalization of professional services). These will be further discussed at the first review.

16. The authorities are improving data quality. Data reporting mechanisms now appear to be in place for the most problematic public enterprises, in support of public enterprise reform and privatization. Elsewhere, the President of the newly independent Statistical Office (ELSTAT) has been identified and his (her) appointment is expected to be approved by Parliament by early-July, while the selection of the Council of the Hellenic Statistical System is almost completed. Although progress has been made in data collection, cooperation of ELSTAT with data providers needs to be improved further, particularly in the areas of health and social security where important data shortfalls continue to plague the interpretation of developments and emergence of concomitant fiscal risks. For that purpose, MoUs are being drafted and a statistical correspondent will be appointed for each of the data-providing institutions to seek compliance. A resident expert appointed by Eurostat is working closely with the authorities to develop regulations of statistical obligations. Efforts are being made to compile quarterly data of the ESA95 general government using direct data whenever possible (this was not possible before), with Q1 data expected to be available in early July. Progress with the implementation of the joint Greek government and EC statistical action plan and the follow up on the K-1 Report on misreporting that was discussed in the Executive Board will be discussed in the first review. 


\section{Box 4. Public Sector Employment and Wage Census}

The authorities are implementing a public employment and wage census to improve transparency over the wage bill. Precise data on general government employment numbers and wage compensation are notoriously lacking in Greece. The census is therefore timely and works toward meeting an end-December structural benchmark. The census will take place July 12-23 and have the following key characteristics:

- $\quad$ Coverage will be broad. It will include the state budget and social security funds by end-September, and by February 2011 the general government (including the military). The type of employment covered will also be broad, including all permanent employees and employees under contracts.

- Type of compensation will include all wages, allowances, and bonuses, including irregular payments such as overtime.

- Implementation pilot. A pilot has been conducted for November 2009, and has achieved coverage of about 80 percent of the general government. The key missing groups were in education and local governments which are highly dispersed.

Expected savings will result from cross-checking eligibility for allowances with information provided to the tax authority (such as tax returns), and from monitoring the amount of allowances paid. This availability of information on the amount of allowances paid and employment will importantly enhance accountability.

\section{STAFF APPRAisal}

17. The authorities have made a strong start with the program, but challenges also remain evident. Staff is impressed with the determination of the authorities to make the program a success. Their task is made more difficult by continued social anxiety over the impact of the measures and the authorities are concerned about the repeated skepticism in the press and among analysts whether Greece can work through the program without a debt restructuring. Greece's weak reputation is presenting credibility costs that can only be overcome by strong and full implementation.

18. The economic response to the program has yet to play out fully, and the program's macro-framework will be reassessed in subsequent reviews. Since the economy is relatively closed, the sharp cutbacks in public spending are beginning to affect activity without a strong response yet from net exports. The authorities need to persevere in 
their efforts to open up the economy, and to improve tax administration which can help tap into the large parallel economy where cushions of wealth and spending are located.

19. Inflation is too high. While the staff clearly underestimated the effects of indirect taxes on headline inflation - we need to revise up the inflation projection in the first review - the lack of evidence that any of the tax increases is being offset by narrower margins in prices points toward serious rigidities in the product markets. The ministry of economy needs to deepen and speed up product and services market reforms, in close consultation with the European Commission.

20. Fiscal developments are encouraging, but risks need to be addressed. The state government deserves recognition for well-executed and tight expenditures, while revenues are broadly on track. Key risks emanate from health spending, social security accounts, local governments, and public enterprises. Better data urgently need to be collected and processed, and the deficits in these off-budget entities require a clear response. These problems have, in fact, been festering for years, but have never been decisively addressed, causing "fiscal black holes" that generate unexpected increases in debt as state guarantees are called and arrears cleared. A demonstration of much stronger control over these entities can materially boost fiscal credibility and help break the adverse trend in spreads.

\section{A strong pension reform is essential to bolster fiscal sustainability and this vital} program for the public. While staff is confident that significant cost cutting is underway in the draft pension reform law, concluding the discussions is made difficult by the absence of a fully quantified actuarial analysis. Staff recommends strong actuarial underpinnings of the pension reform, and if the authorities need to move to parliament fast with the law because the window of opportunity is narrow (i.e. before all actuarial tests can be completed), then adequate contingency plans need to be embedded in the law to correct possible shortfalls once the actuarial results are in.

\section{Banks' liquidity problems and gradual solvency erosion require continued}

vigilance. The assistance provided by the ECB and the fiscal authorities' offer of guarantees to the banking system to facilitate collateral material is vital and welcome. The FSF is almost in place and will soon be endowed with substantial resources, ready to provide support if the currently adequate levels of capital are not sufficient to absorb the expected further losses due to the economic contraction.

\section{Confidentiality considerations are complicating effective engagement of PSI.}

Neither the private sector banks in various countries, nor the ECB in its program of Greek government bond purchases, disclose details of their holdings and trading of Greek exposure. Staff will continue to seek better information on such exposures, which would facilitate the dialogue with the private sector.

24. The importance of very strong reforms for future growth cannot be overestimated. Labor market reform under preparation is sound and needs to be 
implemented forthwith. However, product and services market reforms are too timid for now and need to be strengthened and deepened. The thought persists that Greece's closed nature and inability to generate inflation below the euro-area average, even in the midst of a deep recession, is evidence of poorly contested internal output markets. As expected, strong resistance is being put up by closed professions (e.g. truckers, lawyers, notaries, architects, etc.) and more needs to be done to overcome such resistance. This will also help generate broad support for the program by preserving fairness in the distribution of the adjustment burden between dependent labor, the self employed, and capital owners. The authorities can send a further strong signal to the markets by being uncompromising in their resolve and speed to privatize or close down the numerous state enterprises which have proven to cost tax payers large sums of money, rather than yielding adequate dividends, and which may well be obstacles to more efficient market structure as long as they remain in the public hands.

25. A safeguards assessment of the BoG is in progress and is expected to be completed by the time of the first review of the SBA.

26. Next steps. The staff is encouraged by the progress so far in view of the difficult situation the country faces. The first full review of the program will be conducted during a mission to Athens at end-July, and Board discussion of this review is planned for early September. 
Table 1. Greece: Quantitative Performance Criteria (in billion of Euros, unless otherwise indicated)

\begin{tabular}{|c|c|c|c|c|c|c|c|c|c|c|c|}
\hline & \multicolumn{3}{|c|}{ Performance Criteria } & \multicolumn{8}{|c|}{ Indicative Targets } \\
\hline & Jun-1C & Sep-10 & Dec-10 & Jun-1 & Sep- & & Dec-1 & & Dec-11 & Dec-12 & Dec-13 \\
\hline & Progr. 1/ & Progr. 1/ & Progr. 1/ & Progr. 1/ & Progr. 1/ & & Progr. 1/ & & rogr. 2/ & Progr. 3/ & Progr. 4/ \\
\hline 1. Floor on the modified general government primary cash balance & -5.0 & -4.0 & -5.7 & & .. &.. & &.. & -2.1 & 2.4 & 7.4 \\
\hline 2. Ceiling on State Budget primary spending & 34 & 50 & 67 & & .. &. & &.. & 67 & 68 & 69 \\
\hline 3. Ceiling on the accumulation of new domestic arrears by the general government 5 / & . & .. & .. & & 0 & 0 & & 0 & 0 & 0 & 0 \\
\hline 4. Ceiling on the overall stock of central government debt & 342 & 342 & 342 & & .. &.. & &. & 365 & .. & .. \\
\hline 5. Ceiling on the new guarantees granted by the central government & 2.0 & 2.0 & 2.0 & &.. &.. & &.. & 1.0 & 0.0 & 0.0 \\
\hline $\begin{array}{l}\text { 6. Ceiling on the accumulation of new external payments arrears on external debt } \\
\text { contracted or guaranteed by general government } 5 \text { / }\end{array}$ & 0 & 0 & 0 & & .. & .. & & .. & 0 & 0 & 0 \\
\hline
\end{tabular}

1/ Cumulatively from January 1, 2010 (unless otherwise indicated).

2/ Cumulatively from January 1, 2011 (unless otherwise indicated)

3/ Cumulatively from January 1, 2012 (unless otherwise indicated).

4/Cumulatively from January 1, 2013 (unless otherwise indicated).

5/ Applies on a continuous basis from April [30] onward. 
Table 2. Greece: Structural Conditionality for 2010 1/

1. Reduce public wage bill by cutting bonuses/allowances; and pension bonuses (except minimum pensions).

2. Increase standard VAT rate from 21 to 23 percent and reduced rate from 10 to 11 percent and excise tax rates on alcohol, tobacco, and fuel with a yield of at least $€ 1.25$ billion in the remainder of 2010 .

3. Appoint staff team and leader in GAO responsible for general government in-year cash reporting.

\section{Structural benchmarks}

1. Establish the independent Financial Stability Fund (FSF) to preserve the financial sector's soundness and thus its capacity to support the Greek economy by providing equity support to banks as needed.

2. Adopt and start to implement a reorganization of sub-central government with the aim to reduce the number of local administrations and elected/appointed officials (Kalikrates)

3. Submit to parliament amendments to Law $2362 / 1995$ to (i) require the MoF to present a three-year fiscal and budget strategy, (ii) introduce top-down budgeting with expenditure ceilings for the State budget and multi-year expenditure estimates by line ministry, (iii) introduce standard contingency margins, (iv) require a supplementary budget for any overspending above the contingency, (v) and introduce commitment controls. The amended law should be immediately effective, including in the context of the 2011 budget.

4. The National Actuarial Authority to produce a report to assess whether the parameters of the new system significantly strengthen long-term actuarial balance.

1. Adopt a comprehensive pension reform that reduces the projected increase in public spending on pensions over the

\section{End-September 2010} period 2010-60 to $2 \frac{1}{2}$ percent of GDP.

2. Establish a commitment register in all line ministries and public law entities. Begin publishing monthly data on general government in-year fiscal developments (including arrears).

3. Publish 2009 financial statements of the ten largest loss-making public enterprises, audited by chartered accountants on the official website of the Ministry of Finance.

4. Put in place an effective project management arrangement (including tight MOF oversight and five specialist taskforces) to implement the anti-evasion plan to restore tax discipline through: strengthened collection enforcement and recovery of tax arrears - coordinated with the social security funds - of the largest debtors; a reorganized large taxpayer unit focused on the compliance of the largest revenue contributors; a strong audit program to defeat pervasive evasion by high-wealth individuals and high income self-employed, including prosecution of the worst offenders; and a strengthened filing and payment control program.

1. Publish a detailed report by the ministry of finance in cooperation with the single payment authority on the structure 1. Publish a detailed report by the ministry of finance in cooperation with the single payment authority
and levels of compensation and the volume and dynamics of employment in the general government.

2. Adopt new Regulation of Statistical Obligations for the agencies participating in the Greek Statistical System.

3. Prepare a privatization plan for the divestment of state assets and enterprises with the aim to raise at least 1 billion euro a year during the period 2011-2013.

1/ Structural benchmarks for 2011 will be determined in the reviews for end-September and end-December 2010.
Prior actions

Improves fiscal sustainability; has signaling effect for private sector wage setting.

Improves fiscal sustainability.

Establishes in-year oversight responsibilities of general government fiscal policy.

End-June 2010

Enhances financial stability.

Improves fiscal sustainability.

Improves credibility of the budget and fiscal consolidation program.

Reduces budgetary costs of ageing and improves long-term fiscal sustainability. Increases labor force participation.

Improves fiscal sustainability.

Reduces budget overruns.

Increases transparency of fiscal risks to fiscal sustainability.

Achieves revenue targets and enhances sustainability of the consolidation by increasing burden sharing of the adjustment.

End-December 2010

Reduces wage escalation. Improves transparency of public sector employment.

Enhance confidence in fiscal reporting and support the formulation of fiscal policy. Reduces state intervention in the real economy; improves market efficiency; and cuts fiscal contingencies.

\section{CInternational Monetary Fund. Not for Redistribution}


Table 3. Greece: Selected Economic Indicators

\begin{tabular}{|c|c|c|c|c|c|c|c|}
\hline & 2009 & 2010 & 2011 & 2012 & 2013 & 2014 & 2015 \\
\hline & \multicolumn{7}{|c|}{ Proj. } \\
\hline & \multicolumn{7}{|c|}{ (Percentage change, unless otherwise indicated) } \\
\hline \multicolumn{8}{|l|}{ Domestic economy } \\
\hline Real GDP & -2.0 & -4.0 & -2.6 & 1.1 & 2.1 & 2.1 & 2.7 \\
\hline Output gap (percent of pot. output) & 4.0 & -1.1 & -4.6 & -4.7 & -4.0 & -3.7 & -3.1 \\
\hline Total domestic demand & -2.4 & -7.1 & -5.2 & 0.1 & 1.7 & 1.8 & 2.1 \\
\hline Private consumption & -1.8 & -4.0 & -3.7 & 0.8 & 2.8 & 2.5 & 2.5 \\
\hline Public consumption & 9.6 & -10.6 & -5.1 & -3.6 & -6.6 & -3.2 & -0.1 \\
\hline Gross fixed capital formation & -13.9 & -11.4 & -11.8 & 0.8 & 4.8 & 3.5 & 2.3 \\
\hline Change in stocks (contribution) & 0.0 & -1.0 & 0.0 & 0.0 & 0.0 & 0.0 & 0.0 \\
\hline Foreign balance (contribution) & 0.7 & 3.8 & 3.6 & 1.0 & 0.4 & 0.5 & 0.3 \\
\hline Exports of goods and services & -18.1 & 4.5 & 5.4 & 5.9 & 6.0 & 5.9 & 6.0 \\
\hline Imports of goods and services & -14.1 & -9.7 & -6.1 & 1.6 & 3.8 & 4.6 & 3.7 \\
\hline Unemployment rate (percent) & 9.4 & 11.8 & 14.6 & 14.8 & 14.3 & 14.1 & 13.4 \\
\hline Employment & -1.4 & -2.6 & -3.2 & -0.2 & 0.7 & 0.3 & 0.9 \\
\hline Consumer prices (HICP), end of period & 2.6 & 1.0 & -0.5 & 0.7 & 0.8 & 1.2 & 1.0 \\
\hline Consumer prices (HICP), period average & 1.3 & 1.9 & -0.4 & 1.2 & 0.7 & 0.9 & 1.0 \\
\hline Core prices, period average $1 /$ & 2.3 & 1.9 & $\ldots$ & $\ldots$ & $\ldots$ & $\ldots$ & $\ldots$ \\
\hline \multirow[t]{2}{*}{ GDP deflator } & 1.4 & 1.2 & -0.5 & 1.0 & 0.7 & 1.0 & 1.1 \\
\hline & \multicolumn{7}{|c|}{ (Percent of GDP) } \\
\hline \multicolumn{8}{|l|}{ Balance of payments } \\
\hline Current account & -11.2 & -8.4 & -7.1 & -5.6 & -4.0 & -2.8 & -1.9 \\
\hline Trade balance & -7.7 & -3.5 & -0.2 & 0.6 & 1.3 & 1.9 & 2.4 \\
\hline Export of goods and services & 17.8 & 21.1 & 23.6 & 24.8 & 25.8 & 26.8 & 27.7 \\
\hline Imports of goods and services & 25.5 & 24.6 & 23.8 & 24.2 & 24.5 & 24.8 & 25.2 \\
\hline Total transfers & 0.5 & 0.4 & 0.5 & 0.5 & 0.4 & 0.4 & 0.3 \\
\hline Net income receipts & -4.1 & -5.2 & -7.5 & -6.7 & -5.7 & -5.1 & -4.7 \\
\hline Net international investment position & -83 & -93 & -101 & -104 & -104 & -102 & -100 \\
\hline \multicolumn{8}{|l|}{ Public finances (general government) } \\
\hline Total revenues $2 /$ & 36.9 & 40.0 & 39.0 & 38.5 & 38.2 & 37.2 & 36.3 \\
\hline Total expenditures $2 /$ & 50.4 & 50.5 & 53.2 & 53.9 & 54.0 & 52.3 & 50.6 \\
\hline Primary expenditures $2 /$ & 45.4 & 44.9 & 46.6 & 46.5 & 46.0 & 43.9 & 42.5 \\
\hline Measures (cum.) 3/ & $\ldots$ & 2.5 & 6.7 & 9.0 & 11.0 & 12.6 & 12.2 \\
\hline Overall balance & -13.6 & -8.1 & -7.6 & -6.5 & -4.8 & -2.6 & -2.0 \\
\hline Primary balance & -8.6 & -2.4 & -0.9 & 1.0 & 3.1 & 5.9 & 6.0 \\
\hline Gross debt & 115 & 133 & 145 & 149 & 149 & 144 & 139 \\
\hline \multicolumn{8}{|l|}{ Interest rates and credit } \\
\hline Long-term lending interest rate 4/ & 5.7 & 5.8 & $\ldots$ & $\ldots$ & $\ldots$ & $\ldots$ & $\ldots$ \\
\hline Private credit growth $4 / 5$ / & 4.2 & 3.5 & $\ldots$ & $\ldots$ & $\ldots$ & $\ldots$ & $\ldots$ \\
\hline \multicolumn{8}{|l|}{ Exchange rates } \\
\hline Nominal effective exchange rate $6 /$ & 0.7 & -1.3 & $\ldots$ & $\ldots$ & $\ldots$ & $\ldots$ & $\ldots$ \\
\hline Real effective exchange rate (CPI-based) $6 /$ & 1.7 & 1.2 & $\ldots$ & $\ldots$ & $\ldots$ & $\ldots$ & $\ldots$ \\
\hline Real effective exchange rate (man. ULC-based) 6/ & 3.8 & -0.5 & $\ldots$ & $\ldots$ & $\ldots$ & $\ldots$ & $\ldots$ \\
\hline \multicolumn{8}{|l|}{ Memorandum item: } \\
\hline Nominal GDP (billions of euros) & 237 & 231 & 224 & 228 & 235 & 242 & 251 \\
\hline Nominal GDP (percentage change) & -0.7 & -2.8 & -3.1 & 2.1 & 2.8 & 3.1 & 3.8 \\
\hline
\end{tabular}

Sources: National Statistical Service; Ministry of Economy and Finance; Bank of Greece; and IMF staff estimates.

1/ Core prices exclude energy, food, alcohol, and tobacco.

2/ Excluding unidentified measures.

3/ Measures fully identified up to 2013.

4/ As of March 2010.

5/ Domestic credit growth of households and enterprises.

6/ As of April 2010. 
Table 4. Greece: General Government Operations, 2009-15 1/

\begin{tabular}{|c|c|c|c|c|c|c|c|}
\hline & 2009 & 2010 & 2011 & 2012 & 2013 & 2014 & 2015 \\
\hline & \multicolumn{7}{|c|}{ Projections } \\
\hline & \multicolumn{7}{|c|}{ (Euro billions) } \\
\hline Revenue 2/ & 87.5 & 93.5 & 87.2 & 87.9 & 89.8 & 90.0 & 91.3 \\
\hline Taxes on production, and imports & 26.4 & 32.0 & 28.8 & 29.4 & 30.5 & 32.1 & 33.3 \\
\hline Taxes on income, and property & 18.8 & 18.3 & 16.9 & 17.0 & 17.4 & 18.5 & 18.9 \\
\hline Social contributions & 30.4 & 29.1 & 27.8 & 27.7 & 27.7 & 28.8 & 29.3 \\
\hline Other & 8.8 & 9.1 & 8.7 & 8.9 & 9.1 & 9.4 & 9.8 \\
\hline Capital transfers & 3.1 & 5.0 & 5.0 & 5.0 & 5.0 & 1.2 & 0.0 \\
\hline Primary expenditure 2/ & 107.9 & 99.1 & 104.2 & 106.1 & 108.0 & 106.2 & 106.9 \\
\hline Wages & 29.5 & 26.9 & 27.6 & 27.1 & 26.7 & 26.6 & 27.2 \\
\hline Social benefits & 48.8 & 47.9 & 52.0 & 53.8 & 55.0 & 56.5 & 57.9 \\
\hline Goods and services & 14.5 & 11.0 & 10.6 & 11.2 & 12.1 & 12.2 & 12.3 \\
\hline Subsidies & 0.3 & 0.3 & 0.3 & 0.3 & 0.3 & 0.3 & 0.3 \\
\hline Other current & 3.9 & 3.7 & 3.7 & 3.7 & 3.8 & 3.8 & 3.8 \\
\hline Capital & 10.9 & 9.4 & 10.0 & 9.9 & 10.0 & 6.9 & 5.4 \\
\hline Measures, cumulative & $\ldots$ & $\ldots$ & 14.9 & 20.6 & 25.5 & 30.4 & 30.8 \\
\hline Measures, flow & $\ldots$ & $\ldots$ & 9.2 & 5.6 & 4.8 & 4.6 & 0.0 \\
\hline of which: not yet estimated & $\ldots$ & $\ldots$ & 0.0 & 0.0 & 4.2 & 4.6 & 0.0 \\
\hline Primary balance & -20.4 & -5.6 & -2.1 & 2.4 & 7.4 & 14.2 & 15.2 \\
\hline Interest payments & 11.9 & 13.0 & 14.9 & 17.1 & 18.9 & 20.4 & 20.3 \\
\hline Overall balance & -32.3 & -18.6 & -17.0 & -14.7 & -11.5 & -6.2 & -5.1 \\
\hline \multirow[t]{2}{*}{ Gross debt (Maastricht) } & 273.5 & 307.5 & 324.6 & 339.4 & 350.1 & 349.6 & 348.7 \\
\hline & \multicolumn{7}{|c|}{ (Percent of GDP) } \\
\hline Revenue 2/ & 36.9 & 40.5 & 39.0 & 38.5 & 38.2 & 37.1 & 36.3 \\
\hline Taxes on production, and imports & 11.1 & 13.9 & 12.9 & 12.9 & 13.0 & 13.3 & 13.2 \\
\hline Taxes on income, and property & 7.9 & 7.9 & 7.6 & 7.4 & 7.4 & 7.6 & 7.5 \\
\hline Social contributions & 12.8 & 12.6 & 12.4 & 12.1 & 11.8 & 11.9 & 11.7 \\
\hline Other & 3.7 & 4.0 & 3.9 & 3.9 & 3.9 & 3.9 & 3.9 \\
\hline Capital transfers & 1.3 & 2.2 & 2.2 & 2.2 & 2.1 & 0.5 & 0.0 \\
\hline Primary expenditure 2/ & 45.4 & 42.9 & 46.6 & 46.5 & 46.0 & 43.8 & 42.5 \\
\hline Wages & 12.4 & 11.7 & 12.3 & 11.9 & 11.4 & 11.0 & 10.8 \\
\hline Social benefits & 20.5 & 20.8 & 23.3 & 23.6 & 23.4 & 23.3 & 23.0 \\
\hline Goods and services & 6.1 & 4.8 & 4.7 & 4.9 & 5.1 & 5.0 & 4.9 \\
\hline Subsidies & 0.1 & 0.1 & 0.1 & 0.1 & 0.1 & 0.1 & 0.1 \\
\hline Other current & 1.6 & 1.6 & 1.6 & 1.6 & 1.6 & 1.6 & 1.5 \\
\hline Capital & 4.6 & 4.1 & 4.5 & 4.3 & 4.3 & 2.8 & 2.2 \\
\hline Measures, cumulative & $\ldots$ & $\ldots$ & 6.7 & 9.0 & 11.0 & 12.6 & 12.2 \\
\hline Measures, flow & $\ldots$ & $\cdots$ & 4.1 & 2.4 & 2.0 & 1.9 & 0.0 \\
\hline of which: not yet estimated & $\ldots$ & $\ldots$ & 0.0 & 0.0 & 1.8 & 1.9 & 0.0 \\
\hline Primary balance & -8.6 & -2.4 & -0.9 & 1.0 & 3.1 & 5.9 & 6.0 \\
\hline Interest payments & 5.0 & 5.6 & 6.6 & 7.5 & 8.1 & 8.4 & 8.1 \\
\hline Overall balance & -13.6 & -8.1 & -7.6 & -6.5 & -4.9 & -2.6 & -2.0 \\
\hline Gross debt (Maastricht) & 115.2 & 133.3 & 145.1 & 148.6 & 149.1 & 144.3 & 138.7 \\
\hline
\end{tabular}

Memorandum items:

Nominal GDP (in euro billions)

Source: Greece authorities, and IMF staff estimates.

1/ ESA95.

2/ For 2010 we have included all the measures already taken amounting to 7.5 percent of GDP.

For 2011 onwards, all program measures are shown in a separate line. 
Table 5. Greece: Public Sector Financing Requirements and Sources (Billion of euros, unless otherwise stated)

\begin{tabular}{|c|c|c|c|c|c|c|c|}
\hline & 2009 & 2010 & 2011 & 2012 & 2013 & 2014 & 2015 \\
\hline Gross borrowing need & 68.6 & 73.6 & 55.1 & 57.9 & 53.1 & 70.7 & 76.6 \\
\hline Overall balance & 34.4 & 20.7 & 18.7 & 16.2 & 12.7 & 7.1 & 5.8 \\
\hline Amortization & 29.7 & 37.4 & 35.3 & 40.5 & 40.2 & 69.2 & 75.6 \\
\hline M\&LT & 20.3 & 31.3 & 27.3 & 32.5 & 26.1 & 32.6 & 28.8 \\
\hline Domestic banks & 4.6 & 15.7 & 10.3 & 16.0 & 13.6 & 16.6 & 14.7 \\
\hline BOP & 15.8 & 15.6 & 17.0 & 16.5 & 12.5 & 16.1 & 14.0 \\
\hline ST & 9.4 & 6.1 & 8.0 & 8.0 & 8.0 & 8.0 & 8.0 \\
\hline Domestic banks & 3.9 & 4.2 & 5.0 & 5.0 & 5.0 & 5.0 & 5.0 \\
\hline BOP & 5.5 & 1.9 & 3.0 & 3.0 & 3.0 & 3.0 & 3.0 \\
\hline Exceptional creditors & & & & & 6.1 & 28.6 & 38.9 \\
\hline EU & & & & & 4.5 & 20.8 & 28.3 \\
\hline IMF & & & & & 1.7 & 7.8 & 10.6 \\
\hline Other $1 /$ & 4.5 & 15.5 & 1.2 & 1.2 & 0.2 & -5.6 & -4.8 \\
\hline Gross financing sources & 68.6 & 35.6 & 15.1 & 33.9 & 45.1 & 70.7 & 76.6 \\
\hline Privatization receipts & 0.9 & 0.0 & 1.0 & 1.0 & 1.0 & 1.0 & 1.0 \\
\hline Other & 6.0 & 2.1 & 1.8 & 1.5 & 1.3 & -2.8 & 0.8 \\
\hline Market access & 61.7 & 33.4 & 12.4 & 31.4 & 42.9 & 72.5 & 74.8 \\
\hline M\&LT & 55.6 & 25.4 & 4.4 & 23.4 & 34.9 & 64.5 & 66.8 \\
\hline Domestic banks & 7.5 & 15.6 & 4.8 & 11.4 & 12.0 & 15.4 & 13.9 \\
\hline BOP & 48.1 & 9.8 & -0.5 & 11.9 & 22.9 & 49.1 & 52.9 \\
\hline ST & 6.1 & 8.0 & 8.0 & 8.0 & 8.0 & 8.0 & 8.0 \\
\hline Domestic banks & 4.2 & 5.0 & 5.0 & 5.0 & 5.0 & 5.0 & 5.0 \\
\hline BOP & 1.9 & 3.0 & 3.0 & 3.0 & 3.0 & 3.0 & 3.0 \\
\hline Financing gap & & 38.0 & 40.0 & 24.0 & 8.0 & & \\
\hline EU (8/11 of the gap) & & 27.6 & 29.1 & 17.5 & 5.8 & & \\
\hline IMF ( $3 / 11$ of the gap) & & 10.4 & 10.9 & 6.5 & 2.2 & & \\
\hline Net market access & 32.0 & -4.0 & -22.9 & -9.2 & 8.8 & 31.9 & 38.0 \\
\hline Domestic banks & 16.6 & 0.7 & -5.5 & -4.6 & -1.6 & -1.2 & -0.8 \\
\hline M\&LT & 16.3 & -0.1 & -5.5 & -4.6 & -1.6 & -1.2 & -0.8 \\
\hline ST (net increase) & 0.3 & 0.8 & 0.0 & 0.0 & 0.0 & 0.0 & 0.0 \\
\hline BOP & 15.4 & -4.7 & -17.4 & -4.6 & 10.3 & 33.1 & 38.8 \\
\hline M\&LT & 32.3 & -6 & -17.4 & -4.6 & 10.3 & 33.1 & 38.8 \\
\hline ST (net increase) & -17.0 & 1.1 & 0.0 & 0.0 & 0.0 & 0.0 & 0.0 \\
\hline Rollover rates of existing debt, percent & & 89.4 & 35.0 & 77.4 & 125.7 & 178.6 & 203.5 \\
\hline Total Maastrict debt in billions of euros & 273.5 & 307.5 & 324.6 & 339.4 & 350.1 & 349.6 & 348.7 \\
\hline Exceptional creditors & & 38.0 & 78.0 & 102.0 & 103.9 & 75.3 & 36.4 \\
\hline EU & & 27.6 & 56.7 & 74.2 & 75.5 & 54.7 & 26.5 \\
\hline IMF & & 10.4 & 21.3 & 27.8 & 28.3 & 20.5 & 9.9 \\
\hline percent of quota & & 1110 & 2277 & 2978 & 3033 & & \\
\hline Private sector & 273.5 & 269.5 & 246.6 & 237.4 & 246.2 & 274.3 & 312.4 \\
\hline Total Maastrict debt (percent GDP) & & 133.3 & 145.1 & 148.6 & 149.1 & 144.3 & 138.7 \\
\hline Exceptional creditors & & 16.5 & 34.9 & 44.7 & 44.2 & 31.1 & 14.5 \\
\hline EU & & 12.0 & 25.4 & 32.5 & 32.2 & 22.6 & 10.5 \\
\hline IMF & & 4.5 & 9.5 & 12.2 & 12.1 & 8.5 & 3.9 \\
\hline
\end{tabular}

Sources: Ministry of Finance; and IMF staff's projections.

$1 /$ It includes bank assistance and stock-flow adjustments. 
Table 6. Greece: Summary of Balance of Payments, 2009-15

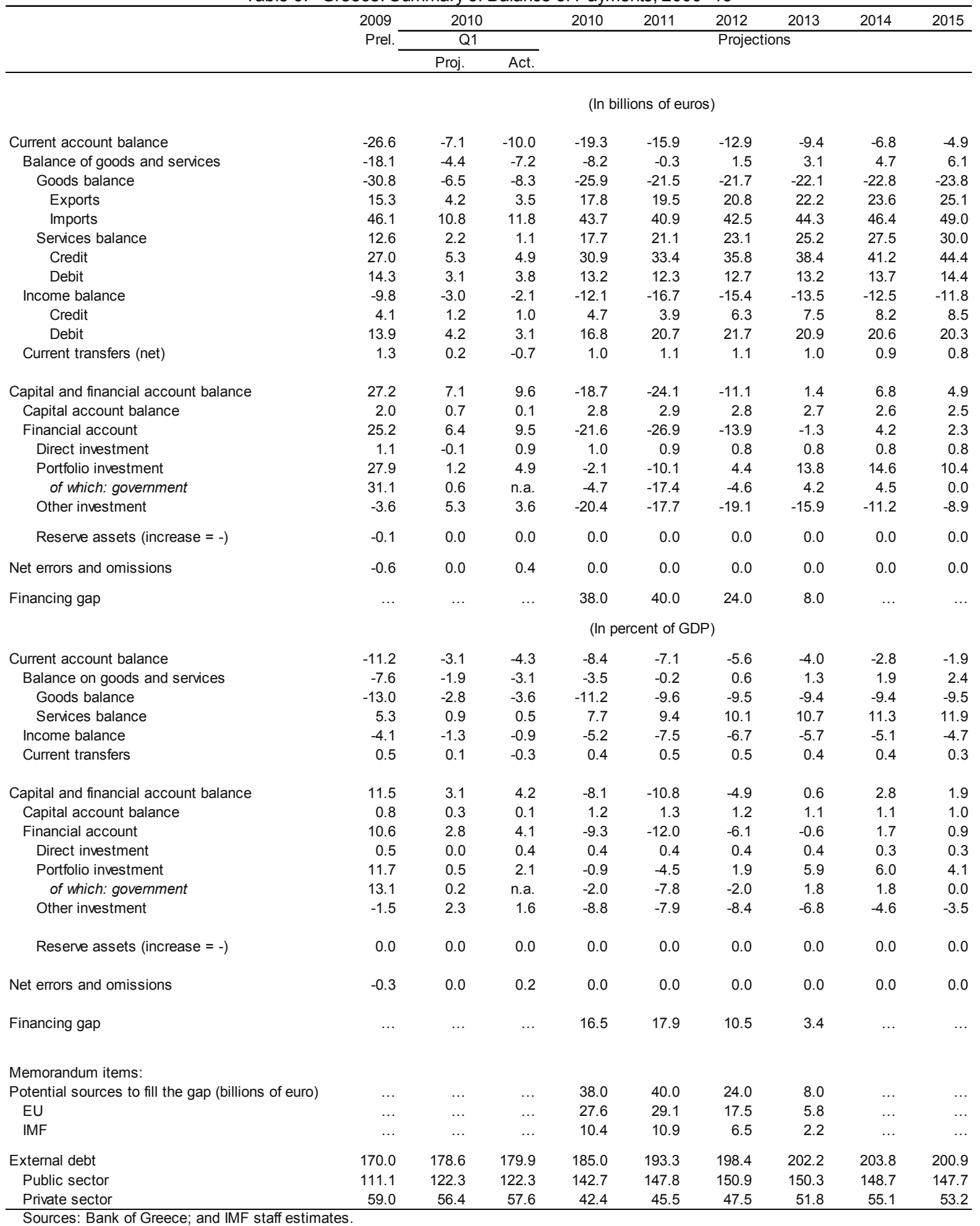


Table 7. Greece: External Financing Requirements and Sources, 2008-15

\begin{tabular}{|c|c|c|c|c|c|c|c|c|}
\hline & 2008 & 2009 & $\begin{array}{l}2010 \\
\text { Proj. }\end{array}$ & $\begin{array}{l}2011 \\
\text { Proj. }\end{array}$ & $\begin{array}{l}2012 \\
\text { Proj. }\end{array}$ & $\begin{array}{l}2013 \\
\text { Proj. }\end{array}$ & $\begin{array}{l}2014 \\
\text { Proj. }\end{array}$ & $\begin{array}{l}2015 \\
\text { Proj. }\end{array}$ \\
\hline GROSS FINANCING REQUIREMENTS & 122.9 & 167.1 & 186.1 & 179.7 & 158.1 & 154.5 & 182.9 & 202.4 \\
\hline Current account deficit & 34.8 & 26.6 & 19.3 & 15.9 & 12.9 & 9.4 & 6.8 & 4.9 \\
\hline Medium- and long-term debt amortization & 19.9 & 28.2 & 22.8 & 28.1 & 25.8 & 25.4 & 47.7 & 55.3 \\
\hline Public sector & 14.6 & 15.8 & 15.6 & 17.0 & 16.5 & 18.7 & 44.7 & 52.9 \\
\hline Banks & 4.5 & 11.3 & 6.8 & 8.7 & 9.1 & 4.8 & 2.5 & 0.5 \\
\hline Corporates & 0.8 & 1.1 & 0.3 & 2.3 & 0.2 & 1.9 & 0.6 & 1.9 \\
\hline Short-term debt amortization & 68.2 & 112.2 & 144.0 & 135.7 & 119.4 & 119.8 & 128.3 & 142.2 \\
\hline Public sector \& BoG & 12.0 & 40.8 & 50.9 & 84.2 & 63.0 & 57.7 & 53.9 & 56.6 \\
\hline BoG 1/ & 10.8 & 35.3 & 49.0 & 81.2 & 60.0 & 54.7 & 50.9 & 53.6 \\
\hline Public sector 2/ & 1.2 & 5.5 & 1.9 & 3.0 & 3.0 & 3.0 & 3.0 & 3.0 \\
\hline Banks & 54.9 & 70.2 & 92.1 & 50.6 & 55.7 & 61.3 & 73.5 & 84.5 \\
\hline Corporates & 1.3 & 1.3 & 1.0 & 0.8 & 0.7 & 0.8 & 0.9 & 1.1 \\
\hline Capital account (net) & 4.1 & 2.0 & 2.8 & 2.9 & 2.8 & 2.7 & 2.6 & 2.5 \\
\hline Foreign direct investment (net) & 1.4 & 1.1 & 1.0 & 0.9 & 0.8 & 0.8 & 0.8 & 0.8 \\
\hline Inward & 3.1 & 2.4 & 2.3 & 2.3 & 2.3 & 2.3 & 2.4 & 2.4 \\
\hline Equities (net) & -0.8 & -0.2 & -0.5 & -0.8 & 0.8 & 1.3 & 1.8 & 2.3 \\
\hline by nonresidents & -3.7 & 0.5 & 0.2 & -0.1 & 1.5 & 2.0 & 2.5 & 3.0 \\
\hline Assets drawdown (- increase) & -30.1 & -26.1 & -7.2 & 7.8 & -12.2 & -17.2 & -17.2 & -12.2 \\
\hline New borrowing and debt rollover & 148.0 & 191.8 & 151.9 & 129.0 & 141.9 & 158.9 & 194.8 & 208.9 \\
\hline Medium and long-term borrowing & 35.7 & 47.8 & 16.3 & 9.5 & 22.1 & 30.6 & 52.6 & 55.4 \\
\hline Public sector & 25.6 & 48.1 & 9.8 & -0.5 & 11.9 & 22.9 & 49.1 & 52.9 \\
\hline Banks & 7.3 & -8.5 & 6.1 & 7.9 & 10.0 & 5.8 & 3.0 & 0.6 \\
\hline Corporates & 2.9 & 8.2 & 0.3 & 2.1 & 0.2 & 1.9 & 0.6 & 1.9 \\
\hline Short-term borrowing & 112.2 & 144.0 & 135.7 & 119.4 & 119.8 & 128.3 & 142.2 & 153.6 \\
\hline Public sector \& BoG & 40.8 & 50.9 & 84.2 & 63.0 & 57.7 & 53.9 & 56.6 & 67.8 \\
\hline BoG 1/ & 35.3 & 49.0 & 81.2 & 60.0 & 54.7 & 50.9 & 53.6 & 64.8 \\
\hline Public sector 2/ & 5.5 & 1.9 & 3.0 & 3.0 & 3.0 & 3.0 & 3.0 & 3.0 \\
\hline Banks & 70.2 & 92.1 & 50.6 & 55.7 & 61.3 & 73.5 & 84.5 & 84.5 \\
\hline FINANCING GAP & $\ldots$ & $\ldots$ & 38.0 & 40.0 & 24.0 & 8.0 & $\ldots$ & $\ldots$ \\
\hline European Union (8/11 of total) & $\ldots$ & $\ldots$ & 25.3 & 26.7 & 16.0 & 5.3 & $\ldots$ & $\ldots$ \\
\hline IMF (3/11 of total) & $\ldots$ & $\ldots$ & 12.7 & 13.3 & 8.0 & 2.7 & $\ldots$ & $\ldots$ \\
\hline in percent of quota & $\ldots$ & $\ldots$ & 1,156 & 1,217 & 730 & 243 & $\ldots$ & $\ldots$ \\
\hline \multicolumn{9}{|l|}{ Memorandum item: } \\
\hline Greece IMF quota (SDR millions) & 823.0 & 823.0 & 823.0 & 823.0 & 823.0 & 823.0 & 823.0 & 823.0 \\
\hline Greece IMF quota (Euro millions) & $1,095.8$ & $1,095.8$ & $1,095.8$ & $1,095.8$ & $1,095.8$ & $1,095.8$ & $1,095.8$ & $1,095.8$ \\
\hline
\end{tabular}

Sources: Bank of Greece, Bloomberg, and staff estimates and projections.

1/ Includes liabilities to Eurosystem related to TARGET.

2/ Includes market instruments and trade credits. 
Table 8. Greece: Core Set of Financial Soundness Indicators for Deposit Taking Institutions, 2000-10

(Percent)

\begin{tabular}{|c|c|c|c|c|c|c|c|c|c|c|c|}
\hline & 2000 & 2001 & 2002 & 2003 & 2004 & 2005 & 2006 & 2007 & 2008 & 2009 & $2010 Q 1$ \\
\hline Regulatory capital to risk-weighted assets $1 /$ & 13.6 & 12.4 & 10.5 & 12.0 & 12.8 & 13.2 & 12.2 & 11.2 & 9.4 & 11.7 & 11.7 \\
\hline Regulatory Tier I capital to risk-weighted assets $1 /$ & 13.5 & 10.9 & 8.8 & 9.8 & 10.0 & 10.9 & 9.9 & 9.2 & 7.9 & 10.6 & 10.6 \\
\hline Nonperforming loans net of provisions to capital & 33.4 & 29.4 & 28.9 & 27.0 & 26.5 & 19.2 & 15.4 & 16.8 & 26.1 & 38.2 & 40.6 \\
\hline Nonperforming loans to total gross loans & 11.7 & 8.3 & 7.4 & 7.0 & 7.0 & 6.3 & 5.4 & 4.5 & 5.0 & 7.7 & 8.2 \\
\hline \multicolumn{12}{|l|}{ Sectoral distribution of loans $2 /$} \\
\hline Consumer credit & 9.3 & 10.6 & 11.3 & 12.3 & 14.3 & 15.2 & 16.3 & 15.0 & 14.1 & 14.0 & 13.0 \\
\hline Lending for house purchase & 18.8 & 21.0 & 24.4 & 26.1 & 27.7 & 31.4 & 33.4 & 34.5 & 32.4 & 35.0 & 35.5 \\
\hline Non-financial corporations & 70.5 & 65.7 & 60.4 & 57.7 & 54.4 & 50.5 & 47.1 & 47.2 & 50.4 & 47.5 & 48.0 \\
\hline Insurance corporations and pension funds & 0.1 & 0.1 & 0.1 & 0.1 & 0.1 & 0.1 & 0.1 & 0.2 & 0.1 & 0.0 & 0.0 \\
\hline Other financial intermediaries & 1.1 & 2.2 & 3.2 & 2.6 & 2.3 & 1.6 & 1.8 & 1.5 & 1.5 & 1.9 & 1.9 \\
\hline Other & 0.3 & 0.4 & 0.6 & 1.3 & 1.2 & 1.2 & 1.4 & 1.5 & 1.5 & 1.6 & 1.5 \\
\hline Return on assets (after taxes) $3 /$ & 1.4 & 1.0 & 0.5 & 0.6 & 0.4 & 0.9 & 0.8 & 1.0 & 0.2 & -0.1 & -0.6 \\
\hline Return on equity (after taxes) $3 /$ & 15.4 & 12.4 & 6.8 & 8.9 & 6.4 & 15.9 & 12.7 & 14.8 & 3.2 & -1.5 & -8.7 \\
\hline Interest margin to gross income $3 /$ & 54.5 & 62.8 & 72.5 & 73.9 & 77.0 & 75.5 & 72.3 & 71.9 & 83.1 & 74.8 & 98.1 \\
\hline Non-interest expenses to gross income $3 /$ & 53.0 & 59.0 & 69.0 & 63.0 & 64.3 & 54.5 & 52.2 & 52.6 & 60.0 & 57.4 & 65.8 \\
\hline Liquid assets to total assets $2 /$ & 46.4 & 41.1 & 39.5 & 37.0 & 33.4 & 34.0 & 33.6 & 35.1 & 38.7 & 45.2 & 45.9 \\
\hline Liquid assets to short-term liabilities $2 /$ & 60.7 & 53.0 & 48.7 & 46.5 & 43.2 & 47.0 & 46.5 & 48.0 & 50.0 & 56.9 & 57.4 \\
\hline Net open position in foreign exchange to capital $1 / 4 /$ & $\ldots$ & 3.5 & 7.2 & 5.7 & 3.5 & 2.8 & 4.8 & 3.9 & 7.9 & 11.7 & 10.8 \\
\hline
\end{tabular}

Source: Bank of Greece.

1/ Data on a consolidated basis.

2/ On an aggregate resident-based approach (i.e. commercial banks, cooperative banks and foreign branches).

3/ From 2004 in accordance with IFRS.

4/ Based on revised figures from 2002 onwards. 
Table 9. Greece: Access and Phasing under the Proposed Stand-By arrangement, 2010-13

\begin{tabular}{|c|c|c|c|c|}
\hline \multirow[t]{2}{*}{ Review } & \multirow[t]{2}{*}{ Availability Date } & \multirow[t]{2}{*}{ Action } & \multicolumn{2}{|c|}{ Purchase } \\
\hline & & & $\begin{array}{l}\text { Millions of } \\
\text { SDRs }\end{array}$ & $\begin{array}{c}\text { Percent of } \\
\text { quota }\end{array}$ \\
\hline & May 9, 2010 & Board approval of SBA & $4,805.9$ & 583.9 \\
\hline First Review & August 30, 2010 & Observance of end-June 2010 performance criteria, completion of first review & $2,162.7$ & 262.8 \\
\hline Second Review & November 30, 2010 & Observance of end-September 2010 performance criteria, completion of second review & $2,162.7$ & 262.8 \\
\hline Third Review & February 28, 2011 & Observance of end-December 2010 performance criteria, completion of third review & $3,604.5$ & 438.0 \\
\hline Fourth Review & May 30, 2011 & Observance of end-March 2011 performance criteria, completion of fourth review & $2,883.6$ & 350.4 \\
\hline Fifth Review & August 30, 2011 & Observance of end-June 2011 performance criteria, completion of fifth review & $1,922.4$ & 233.6 \\
\hline Sixth Review & November 30, 2011 & Observance of end-September 2011 performance criteria, completion of sixth review & $1,201.5$ & 146.0 \\
\hline Seventh Review & February 28, 2012 & Observance of end-December 2011 performance criteria, completion of seventh review & $2,403.0$ & 292.0 \\
\hline Eighth Review & May 30, 2012 & Observance of end-March 2012 performance criteria, completion of eighth review & $1,441.8$ & 175.2 \\
\hline Ninth Review & August 30, 2012 & Observance of end-June 2012 performance criteria, completion of ninth review & $1,441.8$ & 175.2 \\
\hline Tenth Review & November 30, 2012 & Observance of end-September 2012 performance criteria, completion of tenth review & 480.6 & 58.4 \\
\hline Eleventh Review & February 28, 2013 & Observance of end-December 2012 performance criteria, completion of eleventh review & $1,441.8$ & 175.2 \\
\hline Twelfth Review & April 30, 2013 & Observance of end-March 2013 performance criteria, completion of twelfth review & 480.6 & 58.4 \\
\hline Total & & & $26,432.9$ & $3,211.8$ \\
\hline
\end{tabular}

Source: IMF staff projections. 
Table 10. Greece: Indicators of Fund Credit

(In millions of Euros, unless otherwise specified)

\begin{tabular}{|c|c|c|c|c|c|c|c|c|c|}
\hline & 2010 & 2011 & 2012 & 2013 & 2014 & 2015 & 2016 & 2017 & 2018 \\
\hline Disbursements & 11,000 & 11,579 & 6,947 & 2,316 & .. & & . & . & \\
\hline (in percent of quota) & $1,109.5$ & $1,167.9$ & 700.8 & 233.6 & .. & . & .. & . & \\
\hline
\end{tabular}

(Projected Debt Service to the Fund based on Existing and Prospective Drawings)

\begin{tabular}{|c|c|c|c|c|c|c|c|c|c|}
\hline Total & 110 & 637 & 1,263 & 3,683 & 10,243 & 12,524 & 7,788 & 2,996 & 367 \\
\hline Interest & 110 & 637 & 1,263 & 1,910 & 1,956 & 1,271 & 515 & 101 & 5 \\
\hline Exports of goods and services & 0.2 & 1.2 & 2.2 & 6.1 & 15.8 & 18.0 & 10.4 & 3.8 & \\
\hline GDP & 0.0 & 0.3 & 0.6 & 1.6 & 4.2 & 5.0 & 2.9 & 1.1 & \\
\hline
\end{tabular}

(Projected Level of Credit Outstanding based on Existing and Prospective Drawings)

\begin{tabular}{|c|c|c|c|c|c|c|c|c|c|}
\hline Outstanding stock & 11,000 & 22,579 & 29,526 & 30,069 & 21,783 & 10,530 & 3,257 & 362 & \\
\hline (in percent of quota) & 1,110 & 2,277 & 2,978 & 3,033 & 2,197 & 1,062 & 328 & 36 & ... \\
\hline Exports of goods and services (in billion of euros) & 48.6 & 52.9 & 56.6 & 60.6 & 64.8 & 69.5 & 74.8 & 79.8 & 85.2 \\
\hline GDP (in billions of Euros) & 230.8 & 223.7 & 228.4 & 234.9 & 242.2 & 251.4 & 266.7 & 277.4 & 289.9 \\
\hline Euro/SDR rate & 1.20 & & & & & & & & \\
\hline
\end{tabular}

Source: Fund staff projections. 
Table 11. Greece: Monetary Survey

\begin{tabular}{|c|c|c|c|c|c|c|}
\hline & 2005 & 2006 & 2007 & 2008 & 2009 & $\begin{array}{l}2010 \\
\text { Proj. }\end{array}$ \\
\hline & \multicolumn{6}{|c|}{ (Billion of euros) } \\
\hline Assets & 242.1 & 265.5 & 298.7 & 357.7 & 380.4 & 394.9 \\
\hline Credit to the private sector & 156.1 & 180.8 & 213.4 & 233.2 & 224.0 & 217.6 \\
\hline Credit to the government & 62.4 & 59.6 & 58.4 & 55.4 & 72.1 & 72.8 \\
\hline Net credit to non- $€$ residents & -9.2 & -8.7 & -11.9 & 12.0 & 33.8 & 55.3 \\
\hline Other & 27.5 & 28.1 & 33.5 & 51.9 & 45.2 & 43.9 \\
\hline Fixed assets & 5.3 & 5.7 & 5.2 & 5.2 & 5.4 & 5.3 \\
\hline Liabilities & 242.1 & 265.5 & 298.7 & 357.7 & 380.4 & 394.9 \\
\hline Total deposits & 171.7 & 187.7 & 214.5 & 241.1 & 250.0 & 230.6 \\
\hline Other & 46.4 & 51.9 & 54.0 & 86.8 & 89.2 & 124.2 \\
\hline Capital and reserves & \multicolumn{6}{|c|}{ (Percent change) } \\
\hline Total deposits & $7.9 \%$ & $9.3 \%$ & $14.3 \%$ & $12.4 \%$ & $3.7 \%$ & $-7.8 \%$ \\
\hline Credit to the private sector & $17.8 \%$ & $15.8 \%$ & $18.0 \%$ & $9.3 \%$ & $-4.0 \%$ & $-2.8 \%$ \\
\hline Credit to the government & \multicolumn{6}{|c|}{ (Percent of GDP) } \\
\hline Total deposits & 87.9 & 89.2 & 94.7 & 100.8 & 105.3 & 99.9 \\
\hline Credit to the private sector & 79.9 & 85.9 & 94.2 & 97.5 & 94.3 & 94.3 \\
\hline Credit to government & \multicolumn{5}{|c|}{ (Percent) } & 31.5 \\
\hline Memorandum items: & & & & & & \\
\hline Capital to assets & 8.5 & 8.0 & 8.0 & 6.7 & 9.3 & 9.1 \\
\hline Credit to government \& private sector over deposits & 131.0 & 132.2 & 131.6 & 120.8 & 119.2 & 126.8 \\
\hline
\end{tabular}

Sources: Bank of Greece; and IMF staff calculations. 
Table 12. Greece: Modified General Government Cash Balance for Program Monitoring (in billion of Euro, cumulative)

\begin{tabular}{|c|c|c|c|c|c|c|c|}
\hline & 2009 & & & Progr & & & \\
\hline & & Mar-10 & Apr-10 & May-10 & Jun-10 & Sep-10 & Dec-10 \\
\hline & Actual & Actual & Actual $\mathrm{P}$ & Prel. Act. & Progr. & Progr. & Progr. \\
\hline I. State budget & & & & & & & \\
\hline Revenues 1/ & 50.5 & 12.4 & 16.2 & 20.1 & 25.1 & 41.2 & 58.4 \\
\hline Net income Ordinary Budget $(A+B-C)$ & 48.5 & 12.1 & 15.9 & 19.8 & 24.1 & 39.1 & 55.1 \\
\hline A. Recurrent/ordinary revenue & 52.3 & 12.8 & 16.8 & $\ldots$ & 25.8 & 41.6 & 58.6 \\
\hline 1. Direct taxes & 21.4 & 4.4 & 5.4 & $\ldots$ & 9.0 & 15.3 & 21.7 \\
\hline Income taxes & 16.6 & 2.6 & 3.4 & $\ldots$ & 6.3 & 11.5 & 16.6 \\
\hline PIT & 10.9 & 2.2 & 2.8 & $\ldots$ & 4.5 & 7.7 & 10.9 \\
\hline CIT & 3.4 & 0.1 & 0.2 & $\ldots$ & 1.0 & 2.2 & 3.5 \\
\hline Other & 2.3 & 0.3 & 0.4 & $\ldots$ & 0.8 & 1.5 & 2.2 \\
\hline Property taxes & 0.5 & 0.0 & 0.1 & $\ldots$ & 0.3 & 0.7 & 1.0 \\
\hline Tax arrears collection & 2.4 & 0.6 & 0.7 & $\ldots$ & 1.3 & 1.7 & 2.2 \\
\hline Other direct taxes & 1.9 & 1.1 & 1.3 & $\ldots$ & 1.2 & 1.6 & 2.0 \\
\hline 2. Indirect taxes & 28.3 & 7.9 & 10.4 & $\ldots$ & 15.6 & 24.4 & 34.1 \\
\hline Transaction taxes & 17.9 & 4.6 & 6.3 & $\ldots$ & 9.4 & 14.9 & 20.2 \\
\hline VAT & 16.6 & 4.3 & 6.0 & $\ldots$ & 8.7 & 13.6 & 18.5 \\
\hline other & 1.3 & 0.2 & 0.3 & $\ldots$ & 0.8 & 1.3 & 1.7 \\
\hline Consumption taxes & 9.6 & 3.2 & 3.9 & $\ldots$ & 5.8 & 8.8 & 12.9 \\
\hline Tax arrears collections & 0.4 & 0.1 & 0.1 & $\ldots$ & 0.2 & 0.3 & 0.5 \\
\hline Other indirect taxes & 0.4 & 0.1 & 0.1 & $\ldots$ & 0.2 & 0.3 & 0.4 \\
\hline 3. Transfers EU & 0.3 & 0.1 & 0.1 & $\ldots$ & 0.1 & 0.2 & 0.4 \\
\hline 4. Nontax revenue & 2.3 & 0.5 & 0.9 & $\ldots$ & 1.1 & 1.7 & 2.4 \\
\hline B. One-off revenue & 1.1 & 0.3 & 0.4 & $\ldots$ & 0.7 & 1.0 & 1.4 \\
\hline C. Tax Refunds (-) & 5.0 & 1.1 & 1.3 & 1.8 & 2.4 & 3.5 & 4.9 \\
\hline Public investment budget & 2.0 & 0.3 & 0.3 & 0.3 & 0.9 & 2.1 & 3.3 \\
\hline A. EU flows & 1.9 & 0.3 & 0.3 & $\ldots$ & 0.8 & 2.0 & 3.1 \\
\hline B. Own revenues & 0.2 & 0.0 & 0.0 & $\ldots$ & 0.1 & 0.1 & 0.1 \\
\hline Total expenditure $1 / 2 /$ & 83.6 & 16.7 & 22.5 & 29.1 & 39.8 & 60.5 & 79.8 \\
\hline Total ordinary spending & 70.3 & 15.2 & 20.2 & 25.8 & 34.2 & 51.6 & 67.9 \\
\hline Total ordinary primary spending & 58.0 & 12.4 & 16.9 & 20.4 & 26.8 & 40.0 & 54.9 \\
\hline A. Remuneration and pensions & 25.2 & 5.5 & 7.8 & $\ldots$ & 10.8 & 16.5 & 22.5 \\
\hline B. Insurance and Healthcare & 17.6 & 4.0 & 5.1 & $\ldots$ & 8.7 & 12.8 & 18.1 \\
\hline C. Operating and other expenditure and returned resources & 14.5 & 2.7 & 3.8 & $\ldots$ & 7.0 & 10.2 & 13.6 \\
\hline D. Payments in exchange of claims of insurance fund $3 /$ & 0.8 & 0.2 & 0.2 & $\ldots$ & 0.4 & 0.5 & 0.7 \\
\hline Interest expenditure & 12.3 & 2.8 & 3.3 & 5.4 & 7.4 & 11.7 & 13.0 \\
\hline Transfers to hospitals for the settlement of past debt & 1.5 & 0.0 & 0.0 & 0.0 & 0.0 & 0.0 & 0.0 \\
\hline Investment spending & 9.6 & 1.5 & 2.3 & 3.2 & 4.2 & 6.8 & 9.2 \\
\hline Spending on military procurement & 2.2 & 0.0 & 0.0 & 0.0 & 1.4 & 2.0 & 2.7 \\
\hline State Budget primary spending $1 / 2$ ( (variable monitored for $P C$ ) & 71.3 & 13.9 & 19.2 & 23.7 & 32.4 & 48.8 & 66.8 \\
\hline Balance state budget $1 / 2 /$ & -33.1 & -4.3 & -6.3 & -9.0 & -14.7 & -19.3 & -21.4 \\
\hline II. Balance local governments $1 /$ & 0.0 & 0.0 & 0.1 & $\ldots$ & 0.9 & 1.0 & 0.1 \\
\hline III. Balance social security funds $1 /$ & 1.9 & -0.6 & -0.3 & $\ldots$ & 1.9 & 3.1 & 2.6 \\
\hline $\begin{array}{l}\text { IV. Modified general government cash balance } \\
\text { of which: Modified general government primary cash balance }\end{array}$ & -31.2 & -4.9 & -6.5 & $\ldots$ & -12.0 & -15.2 & -18.7 \\
\hline (variable monitored for $P C$ ) & -18.9 & -2.1 & -3.2 & $\ldots$ & -4.6 & -3.5 & -5.7 \\
\hline V. Adjustments 5/ & -1.1 & $\ldots$ & $\ldots$ & $\ldots$ & $\ldots$ & $\ldots$ & 0.1 \\
\hline V. General government balance (ESA 95) & -32.3 & $\ldots$ & $\ldots$ & $\ldots$ & $\ldots$ & $\ldots$ & -18.6 \\
\hline Memorandum items & & & & & & & \\
\hline Floor on the modified general government primary cash balance $6 /$ & $\ldots$ & $\ldots$ & $\ldots$ & $\ldots$ & -5.0 & -4.0 & -5.7 \\
\hline Ceiling on state budget primary spending $6 /$ & $\ldots$ & $\ldots$ & $\ldots$ & $\ldots$ & 34 & 50 & 67 \\
\hline
\end{tabular}

Source: Greek Ministry of Finance and Fund staff projections.

$1 /$ Including measures taken in the context of the 2010 program.

2/ Including spending on military procurement.

3/ For the personnel of the Public Power Company.

4/ Change in net financial assets.

5/ National accounts adjustments and capital transfers to other bodies of general government using bonds.

6/ End-June and end-September targets include a margin to account for deviations from historical seasonality. 